\title{
Silurian-Devonian boundary events and their influence on cephalopod evolution: evolutionary significance of cephalopod egg size during mass extinctions
}

\author{
ŠTĚPÁN MANDA \& JIŘí FRÝDA
}

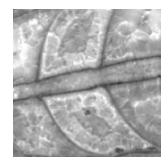

\begin{abstract}
Diversity evolution of 197 of the latest Ludlow-Lochkovian cephalopod species from Bohemia (representing more that 70 percent of all species known worldwide) was analysed and compared with changes in the global carbon cycle in the marine ecosystem. Our results show a distinct relationship between cephalopod species diversity and the global carbon cycle. A progressive increase in $\delta^{13} \mathrm{C}$ values in marine carbonates from the Monograptus lochkoviensis Zone to the end of the Monograptus transgrediens Zone reflects an increase of bioproductivity in the marine ecosystem. This increase was probably caused by a shallowing of the upwelling system, thus importing nutrient-rich water. A progressive cooling during the Přídolí and earliest Lochkovian triggered these changes in the upwelling system. Our data also show an increase in total diversity of cephalopod species, which may be explained by greater availability of new food sources for a period corresponding to the progressive increase in $\delta^{13} \mathrm{C}$ values. In the latest Silurian, $\delta^{13} \mathrm{C}$ reached its maximal values while the Lochkovian is characterized by steady conditions with a decreasing tendency in $\delta^{13} \mathrm{C}$ values. Strong, selective extinction started in the latest Silurian Monograptus transgrediens Zone and continued to the earliest Devonian Monograptus uniformis Zone. This extinction affected benthic and demersal cephalopod species with relatively large eggs and long incubation times. The change in dynamics of the global carbon cycle thus coincides with the beginning of this extinction. An anoxic or hypoxic event in the period between the LAD Monograptus transgrediens Zone (Transgrediens Event) in the latest Přídolí and the base of the Devonian Monograptus uniformis Zone (documented also from offshore sequences from Poland) is considered to be a cause for the extinction of non-pelagic cephalopods. Our study also revealed a need to revise and define all earlier established bioevents in the Silurian-Devonian boundary interval more clearly. Key words: Silurian-Devonian boundary, Klonk Event, Transgrediens Event, cephalopods, carbon isotopes, Prague Basin, peri-Gondwana, extinction, palaeoecology.
\end{abstract}

MANDA, Š. \& FRÝDA, J. 2010. Silurian-Devonian boundary events and their influence on cephalopod evolution: evolutionary significance of cephalopod egg size during mass extinctions. Bulletin of Geosciences 85(3), 513-540 (10 figures, 3 tables). Czech Geological Survey, Prague. ISSN 1214-1119. Manuscript received January 5, 2010; accepted in revised form September 22, 2010; published online September 30, 2010; issued September 30, 2010.

Štěpán Manda, Czech Geological Survey, Klárov 3/131, 11821 Prague 1 Czech Republic; stepan.manda@geology.cz• Jiři Frýda, Czech Geological Survey, Klárov 3/131, 11821 Prague 1 and Faculty of Environmental Sciences, Czech University of Life Sciences Prague, Kamýcká 129, Praha 6 Suchdol, 165 21, Czech Republic; bellerophon@seznam.cz.

The Silurian has been considered as a period with a relatively stable green house climate with the absence of significant extinction events for a long time (see Holland 1991 and Calner 2009 for summaries). Since the nineties of the last century, several prominent extinction events were described from graptolite (Jaeger 1991, Urbanek 1993, Koren' 1993, Štorch 1995, Melchin et al. 1998) and conodont successions (Jeppsson 1990, 1998; Jeppsson \& Aldridge 2000). Later studies of carbon isotopes show that some of these extinctions roughly correspond with carbon isotope excursions and thus reflect the carbon-ocean cycle (Munnecke et al. 2003, Lehnert et al. 2007b, Calner 2008). In addition, the oxygen isotopes suggest dramatic changes in water temperature during the Silurian and indicate periods with an ice-house climate (Lehnert et al. 2007a, Eriksson \& Calner 2008, Calner 2008). Nevertheless, the published considering biodiversity, carbon and oxygen isotope as well as eustatic sea-level data have not yet resulted in generally accepted definitions and explanations of Silurian mass extinction events, particularly due to the lack of precise biodiversity data and the focus on rather small enigmatic groups. A weak point in the existing studies is the unconvincing integration of different approaches, e.g. biodiversity data plotted again isotopic curves. Understanding the Silurian mass extinctions and critically evaluating the existing explanations and models requires the careful collection of further data and their evaluation as claimed by Boucot (1990). 
The extinction events close to the Silurian-Devonian boundary are still poorly understood. Walliser (1985) and Schönlaub (1986) considered the "Silurian-Devonian boundary Event" as a prominent turnover in Palaeozoic faunas, however, no definition or precise data was given. On the contrary, Boucot (1990) and Talent et al. (1993) did not find any significant change in the generic diversity of brachiopods across the Silurian-Devonian boundary interval. Urbanek (1995) defined the Transgrediens Event as graptolite extinction just below the Silurian-Devonian boundary. Nearly $80 \%$ of the 14 graptolite species became extinct. This extinction coincided with the beginning shallowing in the latest Přídolí (Melchin et al. 1998). Later, Jeppsson (1998) introduced the name "Klonk Secundo-Unnamed Event" as a conodont extinction event, which is probably identical with the Transgrediens Event. However, this conodont extinction event is known only from a few sections and there are apparent taxonomic discrepancies (Carls et al. 2007). These bioevents were based on the diversity dynamics in low diversity graptolite and conodont faunas. Both the ecological requirements and the mode of life of these extinct groups remain controversial.

Hladíková et al. (1997) and Buggish \& Mann (2004) described the carbon isotope excursion at the SilurianDevonian boundary, but they did not correlate this excursion with biotic changes. The relation between extinctions and the carbon isotope cycle is a widely discussed topic in connection with many Silurian events (Munnecke et al. 2003, Calner 2008). Except for vague statements that positive carbon isotope excursions correspond with extinctions, there is little evidence to support this view. In addition, recent studies of oxygen isotopes suggest that climatic changes reflect the green-ice house status (Joachimski et al. 2009 for a review). The relationship between diversity, extinctions and the oxygen isotope curve is still poorly understood; in particular more oxygen isotope data is needed.

In the present study, we compared cephalopod diversity fluctuations and the carbon isotope curve from the latest $\mathrm{Si}$ lurian and the earliest Devonian based on several sections in the classic area of the Prague Synform, Bohemia (Prague Basin, Barrandian). The highly elaborated biostratigraphy of this area enables detailed correlations in comparison with many other areas. Note that three GSSP stratotypes for the examined intervals occur in the Prague Synform (Ludlow-Přídolí, Přídolí-Lochkovian, Lochkovian-Pragian). We analysed the diversity evolution of 197 of the latest Ludlow-Lochkovian cephalopod species (representing more than 70 percent of all known species of this interval) and compared its dynamics with changes in the global carbon cycle in the marine ecosystem.

Cephalopods were selected as a model group for testing biodiversity changes across the Silurian-Devonian boundary because they represent an animal group with different habitats and ecological strategies; cephalopods inhabited different environmental settings, but usually are not restricted to specific biofacies. The cephalopods also represent a rather diverse group in the Silurian and Devonian. Currently, the best-documented sedimentary succession around the latest Silurian extinction, the Transgrediens Event, is considered to contain a low graptolite diversity fauna consisting of only 14 species (Melchin et al. 1998), although only two species are known from Bohemia or Poland (Chlupáč et al. 1972). By contrast, the coeval fauna included in our database contains more than 100 cephalopod species worldwide. The main aim of this study is to test whether the Silurian-Devonian boundary events had the same impact on an animal group with different modes of life and whether there is a link between cephalopod diversity and changes in environmental parameters. Carbon isotope composition of marine carbonates (characterizing evolution of the global carbon reservoir in the marine ecosystem) was selected here as a proxy for a description of these changes in the Silurian-Devonian boundary interval.

\section{The Silurian-Devonian boundary and bioevents}

The Silurian and Devonian rocks in central Bohemia, SW of Prague, form a large synform with the axis orientated in a NEE-SWW direction. This synform is affected by several faults (Figure 1). Barrande (1846) divided the SilurianDevonian boundary sequences differently from the present stratgraphic concept. The upper boundary of his "étage Ee2" (late Wenlock-early Lochkovian) included the lowermost Lochkovian beds with a dominance of carbonates. The overlying "étage Ff1" unites sequences of shales and carbonate beds. Barrande's lithostratigraphic units ("étages") were for a long time considered to be also chronostratigraphic units. Krejčí (1877) renamed "étage Ee2" as "budňanské vrstvy" (Budňany beds) and "étage Ff1" as "lochkovské vrstvy" (Lochkov beds). Much later, Prantl \& Přibyl (1948) proposed the name "přídolské vrstvy" (Přídolí beds) for the upper part of the Budňany beds. This subdivision is basically still valid (see Chlupáč 1998, Kříž 1998a).

Prribyl (1940, 1943) established the modern biostratigraphic scale of the Přídolí and Lochkovian when he had subdivided this stratigraphic interval into several graptolitic zones. Slightly later, Chlupáč (1953) described the Silurian-Devonian boundary interval in detail. Horný (1955) proposed to split the carbonate sequences into several horizons characterized by common fossils (e.g., horizon with Dayia bohemica or uppermost Silurian Scyphocrinites Horizon) on the basis of his detailed mapping.

One of the conclusions of the "First international congress on Silurian-Devonian boundary, Prague" in 1958 (Svoboda 1960) was to include the Lochkovian (with the youngest occurrences of graptolites) into the Silurian, and 


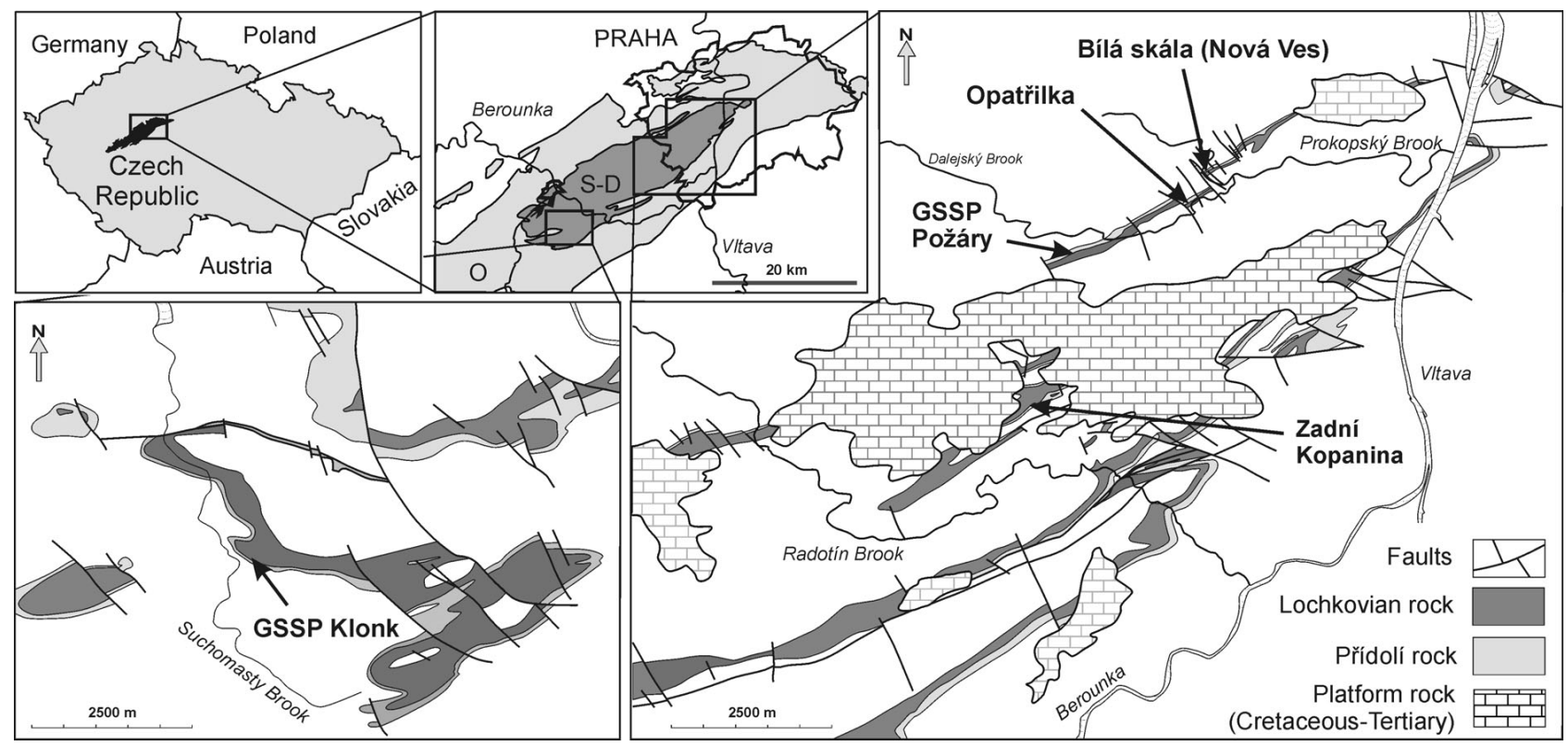

Figure 1. Distribution of the Př́idolí and Lochkovian rocks in the southwestern and eastern part of the Prague Synform and position of the sections including the GSSP Klonk and Požáry sections.

the Pragian was established as the oldest Devonian stage. However, Bouček (1966) found the youngest graptolites within Pragian strata and challenged the concept proposed by the Prague congress. These activities resulted in the Silurian-Devonian boundary being defined at the base of the Monograptus uniformis Zone (Bouček et al. 1966). Subsequently, Chlupáč et al. (1972) studied several Silurian-Devonian boundary sections of the Prague Synform in detail and proposed a more detailed biostratigraphical subdivision of this interval. The Klonk Section near Suchomasty (Fig. 1) in the SW part of the Prague Synform was selected in 1972 as the Silurian-Devonian boundary stratotype (GSSP) during the IGC in Montreal.

Detailed biostratigraphic studies revealed that the British series Ludlow is equivalent only to the Kopanina Formation of the Prague Basin and therefore, it was evident that there is an unnamed time period between the Ludlow and the Lochkovian (Jaeger 1960). This time period was named the Přídolí and is roughly equivalent to the Požáry (formerly Přídolí) Formation (Berdan et al. 1969). Kříž et al. $(1983,1986)$ thoroughly studied the boundary interval between the Kopanina and Požáry formations and the section Na požárech (Fig. 1) near Reporyje was proposed as the GSSP for the base of the Př́dolí (IGC Moscow 1984).

Later detailed palaeontological studies of the Silurian-Devonian boundary interval of the Prague Basin revealed distinct changes in faunal communities [trilobites (Chlupáč 1971, 1983), brachiopods (Havlíček 1999, Havlíček \& Štorch 1999), bivalves (Kř́ǐ 1998b, 1999), cephalopods (Manda 2001), gastropods (Frýda \& Manda 1997), etc.]. However, none of the above mentioned stud- ies evaluated diversity changes quantitatively and thus, it is not known whether the observed faunal changes are considerably different from "normal" levels of faunistic changes at any sequence boundary.

The same is true for several proposed bioevents of the Silurian-Devonian boundary interval such as the SilurianDevonian boundary Event (Walliser 1985), Transgrediens Event (Urbanek 1995), and Klonk Event (Jeppsson 1998). However, all these bioevents were proposed only on the basis of qualitative evaluation of observed faunal changes.

\section{Studied sections, analytical methods and cephalopod database}

\section{Studied sections}

Three well-exposed Silurian-Devonian boundary sections in the vicinity of Prague (Na hradišti-Bílá skála, Opatřilka, and Zadní Kopanina) were studied in detail and sampled for $\delta^{13} \mathrm{C}$ content. Two of the predominantly carbonate sections were studied previously (see below). In the following chapters, basic information on geographic positions, stratigraphic ranges, lithology, and previous studies of the sections are summarized.

\section{Na hradišti-Bílá skála Section}

Large natural outcrops named Bílá skála (White rocks) are located on the western slope of Hradiště hill in the Prokop Valley, about $1100 \mathrm{~m}$ southwest of Butovice Village 
(Fig. 1). The section was first studied and briefly described by Horný (1961, 1962). Later, Vaněk (1963) described a trilobite fauna from the upper part of the $M$. uniformis Zone (early Lochkovian). The Silurian-Devonian boundary interval (starting from bed No. 31 of our section - see Fig. 2) was studied comprehensively by Chlupáč et al. (1972). Because of problems with the identification of some beds in the figured section of Chlupáč et al. (1972, fig. 21), we re-measured the complete section (Fig. 2).

The section begins with shales and platy limestone belonging to the $M$. lochkovensis and M. bouceki zones (Fig. 3D). The first distinct limestone bank bearing $D u$ baria harpyia and Dayia minor communities ( $c f$. Havlíček \& Storch 1999) occurs just above the base of the $M$. bouceki Zone. The mudstone-shale sequence is covered by thin-bedded mudstones some of which bearing cephalopod remains (Fig. 3H). Higher up, thick coarse crinoidal limestone beds occur (Fig. 3F, I), which are covered by several layers of cephalopod limestone bearing a Kopaninoceras fluminese assemblage of the $M$. transgrediens Zone (Fig. 3E, G). The section continues with a bed containing the common brachiopod species Septatrypa latisinuata, and subsequently, characteristic limestone beds with the brachiopod Dayia bohemica can be found (Fig. 3A). Dayia bohemica is less frequent in the following thin-bedded mudstones, which are intercalated with shales. This sedimentary sequence is replaced by brachiopod limestone beds corresponding to the latest Přídolí (trilobite Tetinia minuta) in a younger part of the section (Fig. 3B).

Light grey crinoidal limestone beds overlie these limestones and bear a rich fauna with brachiopods, trilobites (including the index Warburgella rugulosa), and other groups, which already belong to the early Lochkovian (Fig. 3C). Large cephalopod shells are relatively common and thus characteristic for the bed just above the base of the Lochkovian (Fig. 3J). Grey wackestones with less frequent large cephalopod shells form the youngest part of the section (Fig. 3K) and already belong to the late Lochkovian (see Vaněk 1963).

\section{Opatřilka Section}

The Opatřilka Section (Fig. 2) is located in an abandoned quarry on the north slope of Daleje Valley, about $750 \mathrm{~m}$ to the NW from an old chapel in Holyně Village (Fig. 1). The section was already described and measured by Chlupáč et al. (1972). The lowermost part of the measured section consists of mudstones intercalated with shales (M. lochkovensis and M. bouceki zones). A distinct layer of crinoidal limestone with Dayia minor occurs at the base of the M. bouceki Zone. The section continues with cephalopod limestone beds intercalated with thin mudstone and crinoidal limestone beds (M. transgrediens Zone). A diverse fauna of cephalopods, bivalves and gastropods occur in the latter sequence. The cephalopod limestones are overlain by a prominent Septatrypa-bearing brachiopod limestone bank and by a Dayia bohemica-bearing brachiopod bed above. The brachiopod limestones are covered with platy mudstones intercalated with shales or with thin Dayiabearing limestone beds. Brachiopod limestone beds, with the index trilobite Tetinia minuta, characterize the latest Přídolí. The large cephalopods-bearing bituminous limestone beds are covered by mudstones and these beds belong to the basal Lochkovian (identified by FAD W. rugulosa). Crinoidal limestone banks form the youngest part of the section.

\section{Zadní Kopanina Section}

The studied section occurs on a large forested slope in the Mlýnský Brook Valley along the road in Zadní Kopanina Village, about $200 \mathrm{~m}$ east of the bus station "Zadní Kopanina" (Fig. 1). The lower part of the measured section is located in the western portion of this outcrop; the middle and upper parts are located about $80 \mathrm{~m}$ to the east. The section was briefly mentioned by Kř́̌ž (1998b). Stratigraphically, it belongs almost completely to the Přídolí (lowermost part absent) and early Lochkovian (Fig. 2). The section starts with shales and platy limestone beds belonging to $M$. lochkovensis and M. bouceki zones. A characteristic crinoidal limestone layer rich in bivalves is developed at the base of the M. bouceki Zone. Cephalopod limestone beds occur in the upper part of the M. bouceki Zone and lower part of the M. transgrediens Zone (Fig. 4), which are covered by crinoidal and brachiopod limestones with the typical brachiopod species Dayia bohemica. The latest Přídolí is characterized by thin brachiopod limestone and mudstone beds. A few cephalopod limestone beds appear at the base of the Lochkovian (identified here by FAD $M$. uniformis). Higher up, the section continues with early Lochkovian skeletal limestones. The section ends with grey mudstones probably corresponding to the beginning of the "late" Lochkovian.

\section{Carbon isotope analyses}

Carbonates from the late Silurian Požáry Formation and Early Devonian Lochkov Formation were sampled for car-

Figure 2. Nová Ves, Opatřilka, and Zadní Kopanina sections showing biostratigraphy, time slices, bed numbers, lithology, and position of carbon isotope samples (black circles). 
Štěpán Manda \& Jiří Frýda • Silurian-Devonian boundary events and their influence on cephalopod evolution

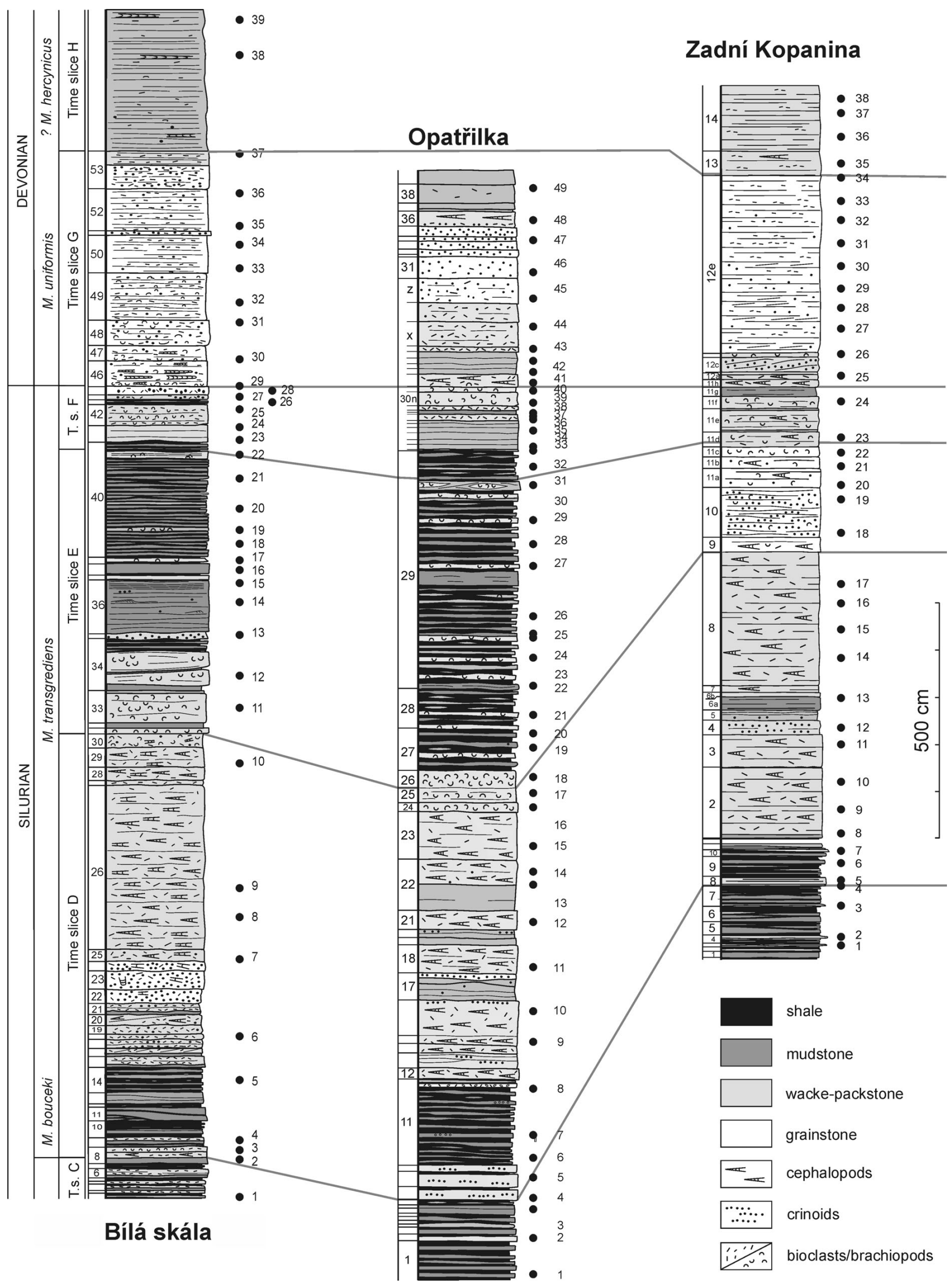


bon isotope analyses from the three sections in the NE part of the Prague Synform described above. These sections (Bílá skála, Opatřilka, and Zadní Kopanina) are generally characterized by sedimentation in relatively shallow-water environments. The carbon isotope record of these sections has never been studied in contrast to the Klonk Section (GSSP) in the SW part of the Prague Basin (Hladíková et al. 1997, Buggisch \& Mann 2004) and the Požáry Quarry (GSSP) in the eastern part of the Prague Basin (Buggisch \& Mann 2004). The sections discussed above were sampled in detail from the carbonate beds just below the Přídolian Monograptus bouceki Zone to the beginning of the Lochkovian Monograptus hercynicus Zone.

All $\delta^{13} \mathrm{C}$ sampling was related to the number of the beds (Fig. 2). In addition to the carbon isotope analysis, thin sections from the different lithologies were studied for additional facies information. A few milligrams of rock powder (preferably micrite) were recovered using a dental drill from rock samples or polished slabs. Where possible, mudstones and wackestones were sampled, but analyses were also done on grainstones in which micrite was absent. Carbonate samples were decomposed in a vacuum using $100 \%$ phosphoric acid at a temperature of 25 degrees Celsius. The carbon and oxygen isotopic composition of the released $\mathrm{CO}_{2}$ was measured with a Finnigan Mat 251 mass spectrometer. All values are reported in \%o relative to the V-PDB by assigning a $\delta^{13} \mathrm{C}$ value of $+1.95 \%$ and a $\delta^{18} \mathrm{O}$ value of $2.20 \%$ o to NSB 19. Accuracy and precision was controlled by replicate measurements of laboratory standards and was greater than $\pm 0.1 \%$ o for both carbon and oxygen isotopes.

\section{Stratigraphic division of Prídolí-Lochkovian used for analysis}

Our analysis is focused on the comparison of cephalopod diversity with the course of the $\delta^{13} \mathrm{C}$ signal across the Silurian-Devovian boundary beds. Data on the stratigraphic position of each $\delta^{13} \mathrm{C}$ sample for the three profiles are very precise (see Fig. 2). This is not true for all cephalopod diversity datasets (see details above). Our priority was to include all known cephalopod species in the analysis and to use the same scale for both datasets. For this reason, eight stratigraphic time slices $(\mathrm{A}-\mathrm{H})$ were selected (see their definition below) and these were used for analysis of both biodiversity and $\delta^{13} \mathrm{C}$ changes.

Time slice A (latest Ludlow) corresponds to the Monograptus fragmentalis Zone (Kř́ž 1998b) and is roughly identical with the "Prionopeltis archiaci Horizon" as described by Horný (1955). This time slice begins with the LAD Monograptus latilobus and ends with the FAD Pristiograptus parultimus (Manda \& Kříž 2006).

Time slice B unites the two-ealiest graptolite zones of the Přídolí, Pristiograptus parultimus and Pristiograptus ultimus zones, which are relatively easily recognisable in the majority of sections (Kř́ž et al. 1986). This time slice covers the period from FAD Pristiograptus parultimus to FAD Monograptus lochkoviensis.

Time slice C corresponds to the Monograptus lochkoviensis Zone in the sense of Kříz et al. (1986). It starts with the FAD Monograptus lochkoviensis and ends with the FAD Monograptus bouceki.

Time slice D unites more than two graptolite zones, the Monograptus bouceki and Monograptus perneri zones, and the lower part of the Monograptus transgrediens Zone. As mentioned previously by Chlupáč et al. (1972) and Kříž et al. (1986), determination of the Monograptus perneri Zone and of the base of the Monograptus transgrediens Zone (interval zone) is difficult in some sections. Nevertheless, the first occurrence of the characteristic brachiopod Dayia bohemica is a good stratigraphic marker in the majority of Prague Basin sections (Chlupáč et al. 1972). For this reason, this stratigraphic level was used here as the end of Time slice D.

Time slice E starts at the level of FAD Dayia bohemica and ends at LAD Monograptus transgrediens. Its upper boundary is easily recognisable in most sections of the Prague Basin, except for those with purely carbonate rocks. However, in the latter sections, the level of LAD Dayia bohemica may be used as a proxy for the LAD of Monograptus transgrediens because the characteristic brachiopod species, Dayia bohemica, ends just above it in all studied sections of the Prague Basin where both taxa are present (Chlupáč et al. 1972).

Time slice F includes a period between the LAD of Monograptus transgrediens and FAD of Monograptus uniformis and is easily recognisable in all the studied sections (Chlupáč et al. 1972).

The FAD of Monograptus uniformis is internationally accepted as a marker for the base of the Devonian (for a summary see Chlupáč 1998) and therefore, it is selected here as the lower boundary of Time slice G. The upper boundary of Time slice $G$ corresponds to the FAD Monograptus hercynicus. Time slice $\mathrm{G}$ is thus equal to the Monograptus uniformis Zone, which was used as an equivalent for the informal unit "lower Lochkovian" by Chlupác (1977). The lower boundary of Time slice G is also easily recognisable by the appearance of newly occurring bivalves (Kř́̌̌ 1999, 2008a, b), trilobites (Chlupáč 1971, Chlupáč et al. 1972), cephalopods (Manda 2001), and gastropods (Frýda \& Manda 1997).

Time slice $\mathrm{H}$ starts at the FAD of Monograptus hercynicus and ends at the Lochkovian-Pragian boundary. It is thus equivalent to the Monograptus hercynicus Zone. As described in detail by Chlupáč (1998), recognition of the lower boundary of the latter zone is sometimes difficult. However, the first appearance of some new faunal elements coinciding with the FAD of Monograptus 
hercynicus (e.g., the brachiopod Howellela inchoans, the bivalve Hercynella, first dacryoconarids, etc.) and the disappearance of some "early Lochkovian taxa" (the trilobite Tropidocare index, scyphocrinids, and graptolite Monograptus uniformis) may be used as an indirect indicator of that stratigraphic level (Chlupáč 1977).

\section{Cephalopod biodiversity data}

Late Silurian to Early Devonian cephalopod faunas of the Prague Basin were first studied comprehensively by Barrande (1865-1877), who described numerous cephalopod species of the genera Orthoceras, Cyrtoceras, Phragmoceras, Gomphoceras, Ophioceras, Trochoceras, Ascoceras, and Nautilus. J. Barrande placed the cephalopod faunas of the latest Silurian and lowermost Devonian in his "étage Ee2", but younger Lochkovian faunas to "étage Ff1". Barrande (1877) was a pioneer in cephalopod research in the Barrandian and already described the distinct decrease in cephalopod diversity in his "étage Ff1". Novák (1886), who made a new detailed revision of cephalopod fauna of the latter "étage", confirmed Barrande's observations and described only one new cephalopod species in addition to those previously described by J. Barrande. Hyatt (1883-84, 1894, 1900), and Foerste (1926) were the first authors who undertook a taxonomic revision of Barrande's cephalopod species (a detailed historical review of taxonomic studies on Bohemian cephalopod faunas was published by Gnoli 1997). However, the majority of these revisions were not based on studies of the actual fossils, but only on a re-evaluation of Barrande's descriptions and figures (see Manda \& Turek 2009a). Only a limited number of the published studies were based on direct examinations of Barrande's original materials plus newly collected cephalopod specimens from Bohemia (Horný 1956, 1965; Marek 1971; Turek 1975, 1976, 2008, 2010; Kolebaba 1977; Stridsberg \& Turek 1997; Manda \& Turek 2009c). A general overview of cephalopods from the Přídolí and Lochkovian was published by Turek and Marek in Kříž et al. (1986) and by Manda (2001). During the intense mapping after the Second World War, a large amount of new fossil material including cephalopods from many new sections and facies was collected from the latest Silurian and Early Devonian strata of the Prague Basin (Horný 1955, Chlupáč 1953, Chlupáč et al. 1972, Kř́̌ž et al. 1986). Even though J. Barrande had previously evaluated fossil material from only a limited number of localities from this stratigraphic interval, his studies included almost all known species. Only a few new cephalopod species were found later in this newly collected fossil material. The surprisingly high diversity of Př́dolí cephalopod faunas of the Prague Basin led Dzik $(1982,1984)$ to the conclusion that Barrande had not recognized the intraspecific variability of cephalopod species and that the real number of cephalopod species was much lower. However, Turek \& Marek (1986) analysed examples mentioned by Dzik (1984) and noted that Barrande's species were correctly established. Barrande and other palaeontologists of the nineteenth century used widely defined morphological genera for newly established cephalopod species, however he united them into smaller groups within each genus, which were characterised by sharing distinct shell features. Barrande's groups were often equal to later introduced genera or families. The vast majority of new revisions of Bohemian cephalopods preserved Barrande's species and the number of species that were synonymised is relatively low (e.g. Marek 1971, Stridsberg 1985, Turek 2008, Manda 2008, Manda \& Turek 2009b, c).

For an evaluation of changes in cephalopod biodiversity, the data on the stratigraphic distribution of all described late Ludlow to late Lochkovian cephalopod species of the Prague Basin from various published and unpublished sources have been summarised. Many of the described cephalopod species are relatively rare and often, only specimens from old collections are available, thus lacking precise stratigraphic information. In addition, the vast majority of cephalopod species have not been revised since Barrande's classical monographs and some species were not found again later (e.g. Gnoli 1997). Our aim was to include all known cephalopod species in this analysis. The uncertainty in stratigraphic position of some cephalopod species allowed us to split the late Ludlow-late Lochkovian period into eight time slices $(\mathrm{A}-\mathrm{H})$. At present, this is the most detailed stratigraphic subdivision of the studied period if all cephalopod species of the Prague Basin are included in the analysis. Based on the obtained dataset, we performed simple diversity analyses including counts of boundary-crossing genera of all cephalopod groups. Cephalopods are a rapidly evolving group and for this reason, we also counted the diversity of cephalopod species known from only one stratigraphical time slice (singletons). In addition to simple diversity measures (i.e., total diversity, mean standing diversity), we tabulated the number of cephalopod species originating (FAD) or ending (LAD) within each of the eight time slices (A-H). The unequal length of the stratigraphic time slices used biases the resulting pattern of the total biodiversity (i.e., number of species present in each stratigraphic time slice). At present there are, however, no exact datations available on the duration of these time slices and in addition, data on the duration of the Přídolí as well as the Lochkovian is very inaccurate (Gradstein et al. 2004, Kaufmann 2006). Thus, there is no possibility to divide the number of cephalopod species present in each time slice by its duration and thereby calculate absolute diversity parameters. Furthermore, the lack of absolute dating of boundaries of the selected time slices A-H cannot be substituted for by estimation of the relative 
Table 1. Diversity of Přídolí and Lochkovian cephalopods.

\begin{tabular}{|c|c|c|c|c|c|c|c|c|}
\hline Time slice & A & $\mathrm{B}$ & $\mathrm{C}$ & $\mathrm{D}$ & $\mathrm{E}$ & $\mathrm{F}$ & G & $\mathrm{H}$ \\
\hline Number of species & 62 & 53 & 31 & 97 & 110 & 21 & 28 & 24 \\
\hline Crossing lower boundary & - & 40 & 25 & 31 & 96 & 19 & 7 & 11 \\
\hline Crossing only lower boundary & - & 22 & 0 & 1 & 78 & 13 & 4 & - \\
\hline Crossing only upper boundary & - & 7 & 6 & 66 & 1 & 1 & 8 & - \\
\hline Crossing both boundaries & - & 18 & 25 & 30 & 18 & 6 & 3 & - \\
\hline Singletons & - & 6 & 0 & 0 & 13 & 1 & 13 & - \\
\hline Mean standing diversity & - & 32.5 & 28.0 & 63.5 & 57.5 & 13.0 & 9.0 & - \\
\hline Mean standing diversity + singletons $/ 3$ & - & 34.5 & 28.0 & 63.5 & 61.8 & 13.3 & 13.3 & - \\
\hline Origination rate & - & 0.25 & 0.19 & 0.68 & 0.13 & 0.10 & 0.75 & 0.54 \\
\hline Extinction rate & 0.35 & 0.53 & 0.00 & 0.01 & 0.83 & 0.67 & 0.61 & - \\
\hline
\end{tabular}

duration of the time slices inferred from the sedimentary record (i.e. from a comparison of relative thickness of individual stratigraphic time slices or from numbers of regular sedimentary cycles) because such data are also lacking. Moreover, the studied sections are characterized by shallow water carbonate sedimentation with different carbonate facies. Presence of hiatuses in such a shallow water environment (carbonate platform) is rather typical. Therefore, the comparison of relative thickness of individual time slices with different carbonate facies also cannot be used for the estimation of their duration. To eliminate the bias produced by the different duration of the time slices, we calculated variables such as mean standing diversity and relative origination and extinction rates. The latter measures are defined as the number of originating (or ending) species divided by total number of cephalopod species being present within the particular time slice.

Cephalopods were selected as a model group to test biodiversity changes across the Silurian-Devonian boundary time slice for several reasons. Firstly, the cephalopod fauna of the Prague Basin was highly diversified and 197 cephalopod species were described from the latest Ludlow-late Lochkovian period (Table 1). Analysis of all cephalopod occurrences (ŠM, unpublished dataset) showed that Bohemian species represent more than 70 percent of all known cephalopod species from this stratigraphic time slice (Table 2). We have more knowledge on the stratigraphic ranges of individual cephalopod species from the Prague Basin than from other areas of the world. Secondly, all known cephalopod faunas from Gondwana, peri-Gondwanan terrains, Avalonia, and particularly Baltica were highly diversified but almost identical in whole regions. All these facts indicate that the analysis of biodiversity of the Prague Basin cephalopod faunas has global rather than only regional significance.

In addition, the latest Ludlow-late Lochkovian cephalopod fauna of the Prague Basin includes members of seven orders (Actinoceratida, Ascocerida, Discosorida, Oncocerida, Orthocerida, Pseudorthocerida, and Tar- phycerida) with different shell morphologies and different juvenile and adult life strategies (Fig. 5, see also the next chapter). These data make it possible to analyse the impact of the changing carbon cycle on cephalopod species with different life strategies (Fig. 5).

The data on stratigraphic ranges of individual cephalopod species as well as on their shell morphologies and ontogenetic strategies were evaluated by standard numerical methods. Jaccard and Dice (Sorensen) association similarity indices were selected for evaluating the presence/absence data and measuring the relative distance between each of the eight time slices. Cluster analysis was utilised for identifying hierarchical groupings within the cephalopod faunas. The unweighed pair-group average (UPGMA) and single linkage (nearest neighbour) algorithms were selected for this analysis from a large number of possible algorithms. In the UPGMA algorithm, the clusters are joined based on the average distance (similarity) between all members in the two groups (faunas). By contrast, clusters in the single linkage algorithm are joined based on the smallest distance between the two groups.

\section{Cephalopod mode of life}

Three different characteristics of cephalopod species (size of embryonic shell, juvenile mode of life, and adult mode of life) were included in our analysis (Fig. 5). All published data as well as hitherto unpublished data on late Ludlow to Lochkovian cephalopod species were carefully evaluated and tabulated with respect to the above-mentioned characteristics. A description and brief definition of the selected features are summarised in the following paragraphs.

\section{Cephalopod embryonic strategies}

Cephalopods, in contrast to some other molluscan classes, have a simple ontogeny lacking a true larval stage. Hatching 
cephalopods are morphologically similar to adults. Generally two basic embryonic strategies may be found in cephalopods. Engeser (1996) suggested using the size of the embryonic shell and presence or absence of a cicatrix as a tool for determination of yolk quantity in the eggs. A small spherical embryonic shell indicates a small embryo with a small yolk sac. Relatively large embryonic shells with a cicatrix indicate a rich yolk supply in the eggs such as in the living Nautilus (see also Kröger 2006). The juvenile cephalopods with a small apex without a cicatrix may be considered as planktotrophic because early hatching animals did not have enough food and probably lived in the water column as macro-planktonic predators. Cephalopods having a large apex with a cicatrix (i.e. large, yolk rich eggs) had a much longer incubation time and hatching animals were benthic. Engeser (1996) proposed distinguishing these two types of early cephalopod ontogeny by morphological characters of their early shell. However, the distribution of early post-hatching shells in different sedimentary facies may also indicate the type of early cephalopod strategy. Small embryonic shells of cephalopods considered to be planktotrophic also commonly occur in deeper water sediments (shales) together with juvenile bivalve and gastropod shells (Kolebaba 1973, 1977; Kř́iž 1998b, unpublished data). Their occurrence in deeper water sediments provides evidence for their living early post-hatching in the water column as macro-plankton. In contrast the early post-hatching cephalopod shells considered to have adopted a lecitrophic strategy (i.e., shells with a large embryonic chamber) occur only in shallow water facies and in comparison to the adults have a reduced geographic distribution. Thus hatching places occur only in part of areas inhabited by adults and these embryonic shells do not occur in shales or in dysoxic facies (Manda 2008). Facies distribution of these two basic types of embryonic shell testifies well to the interpretation of early shell morphology proposed by Engeser (1996).

Pseudorthoceratids have a cup-like and slightly curved shell apex with cicatrix, but a straight shell with cameralintrasiphonal deposits. Their adult distribution pattern resembles nautiloids, but juvenile post-hatching shells also occur in deeper water sediments suggesting life in the water column.

\section{Cephalopod adult strategies}

Examination of the early and adult shell morphology as well as of the distribution of cephalopod shells in different facies allowed the recognition of changes in the mode of life in late Ludlow to Lochkovian cephalopods. Cephalopod species having the same mode of life during early post-hatching stages may have quite different life strategies as adult animals and vice versa. Evaluation of all avail- able data on the late Ludlow-Lochkovian cephalopods revealed seven basic types of life strategy, which can be used for biodiversity analysis and are described briefly below (Fig. 5).

\section{Pelagic cephalopods}

This group comprises cephalopods, which are pelagic during their entire life. It encompasses orthocerids with a small spherical apex, which is sometimes constricted as in bactritoids. The diameter of the embryonic shell usually varies between 0.3-1 mm (Ristedt 1968, Kolebaba 1973, Serpagli \& Gnoli 1977). The shell of pelagic orthocerids is straight with a shallow apical angle and a thin, central or slightly subcentral siphuncle. Cameral deposits are absent or restricted only to the apical part of the phragmocone (e.g., Sweet 1964, Dzik 1984). This type of shell morphology was interpreted as reflecting a vertical orientation in life and that the shell passively drifted with the water current (for a summary see Dzik 1984, Westermann 1998, Mutvei 2002). Maximal shell diameter does not usually exceed $20 \mathrm{~mm}$. At least two convergent groups of pelagic orthocerids occured in the Silurian times: the Michelinoceratidae (Kopaninoceras, Michelinoceras) with a spherical apex and the Arionoceratidae (Arionoceras) with a contracted apex (for details see Kolebaba 1975, Dzik 1984).

A special shell adaptation was found in the genus Parakionoceras (?Arionoceratidae; see Dzik 1984) which has empty, longitudinal cavites between the inner and outer shell wall (Barrande 1865-1877, Kolebaba 1977) probably improving buoyancy control. Pelagic orthocerids are a dominant part of the cephalopod faunas in cephalopod limestone biofacies (Figs 3, 4; Ferretti \& Křriž 1995, Kř́iž 1998b) and shales (Turek 1983), but they are known from all facies. Pelagic orthocerids usually represent cosmopolitan taxa (see Gnoli 2003). The rate of morphological change in individual evolutionary lineages of the pelagic orthocerids is very low. These species usually had long stratigraphic ranges. For example, the species Parakionoceras originale is known from the Wenlock up to the Lochkovian and the genera Kopaninoceras, Michelinoceras, Arionoceras and Parakionoceras range from the late Llandovery to the Emsian or even to younger strata (Barrande 1865-1877, Zhuravleva 1978). The diversity of pelagic cephalopods is usually low.

\section{Nektonic forms with a pelagic early stage}

This group unites orthocerids belonging to two closely related families, the Plagiostomoceratidae and the Sphooceratidae, with uncertain systematic positions within the order Orthocerida (Dzik 1984, Marek 1998, Zhuravleva \& Doguzhayeva 2004). Plagiostomoceratids have a small spherical embryonic chamber with a diameter less than 
$1 \mathrm{~mm}$, typically about $0.5 \mathrm{~mm}$. Their juvenile shell is constricted in the area of the first few phragmocone chambers (Ristedt 1968). The morphology of embryonic and early shell (no hyponomic sinus and the usually smooth shell) suggests that the early mode of life was pelagic as in other orthocerids. Cephalopods placed in this group have a straight adult shell and well developed cameral deposits. According to Flower (1957), the cameral deposits functioned as a counterweight, helping to orient their shell horizontally during life. In some species, the siphuncle was even open in the distal part of the phragmocone, connecting phragmocone chambers with the siphuncle (see Kolebaba 1999, 2002). The shell aperture is typically oblique, expanding on the ventral side, and the hyponomic sinus is well developed. Septa are commonly modified (truncation; see Barrande 1865-1877) and in some species (Sphooceras) the apical part of the phragmocone was periodically discarded (Turek, unpublished data). In cross section, the shell is subcircular and usually laterally compressed. Maximal shell diameter was about $20 \mathrm{~mm}$. The above-described shell morphlogy was interpreted as an adaptation for active swimming, resembling that of some coleoids (see Flower 1957).

The genus Murchisoniceras (Ludlow-Přídolí; Babin 1966) is closely related to the plagiostomoceratids and may represent an exception to the typical live mode of Plagiostomoceratidae. Species of this genus have a large shell with extensive cameral deposits (Barrande 1865-1877), suggesting a demersal rather than a nektonic mode of life in the adult stage. The Plagiostomoceratidae as well as the Sphooceratidae appeared in the early Silurian and their relationship to the Ordovician orthocerids is uncertain (see Dzik 1984). Diversity among nektonic orthocerids is always low with usually one common and a few rare species per assemblage. Plagiostomoceratids are generally long ranging species with a large geographic distribution (e.g. Plagiostomoceras placidum in Lochkovian strata). The rate of change in shell morphology in individual lineages is relatively slow, but much higher than in pelagic orthocerids. Nektonic orthocerids occur in slope facies, but are most abundant close to the margin of carbonate platforms. Faunal assemblages dominated by plagiostomoceratids are relatively common.

\section{Nektobenthic adults with a pelagic early stage}

Some orthoceratids and members of the family Lechritrochoceratidae (Tarphycerida, Barrandeocerina) are united in this group. These orthocerids have a spherical early shell without constriction, the diameter varies between 1-2 mm and they are straight or slightly curved (Cyrtocycloceras, Dawsonocerina: Barrande 1865-1877, Dzik 1984; Dawsonoceras: Kröger \& Isakar 2006). During later ontogeny, various shell modifications may be developed (at shell size about 1-2 cm) including annulations, various types of sculpture, and a hyponomic sinus. The shell may be slightly curved and the angle of its expansion usually increases. These modifications are probably caused by the change from a pelagic to a nektobenthic mode of life. Such shell adaptations connected with a nektobenthic mode of life were developed independently in members of the families Arionoceratidae and especialy Michelinoceratidae. Adult nektobenthic orthocerids occur typically in assemblages with a low diversity of demersal nautiloids (e.g. in early Lochkovian). For example the species Kopaninoceras fluminese (for description see Serpagli \& Gnoli 1977) has an early shell similar to other pelagic orthocerids, but during later ontogeny distinct straight annulation is developed on the shell (Fig. 4F). These annulae become oblique during subsequent shell growth. In addition the straight shell aperture becomes oblique and a distinct hyponomic sinus appears. Closely related families to the Orthoceridae, the Paraphragmitidae and the Dawsonoceratidae both probably had a nektobenthic mode of life as adults. A well-known example is the Silurian Cyrtocycloceras (see Marek 1971).

In addition to some orthocerids described above, members of the tarphyceratid family Lechritrochoceratidae belong to this group. These cephalopods have a secondarily reduced embryonic shell lacking a cicatrix. Their early shells are straight or slightly curved, but the more adult shells become curved or coiled, bearing characteristic annulations on their surface (Turek 1975, 2010). Such shell morphology resembles that of some orthocerids (Paraphragmitidae). This morphological convergence previously caused some taxomonical problems. For example, the lechritrochoceratoid Calocyrtoceras (Ludlow-Přídolí)

Figure 3. Nová Ves, Bílá skála Section. • A - upper part of the Požáry Formation, Přídolí, late M. transgrediens Zone, boundary between cephalopod and brachiopod (Dayia bohemica) limestones. - B - uppermost part of the Požáry Formation, Přídolí, latest M. transgrediens Zone, thin-bedded mudstones intercalated with shale and overlaying skeletal limestone with Tetinia minuta just bellow base of the Devonian. $\bullet \mathrm{C}-\mathrm{Silurian-Devonian}$ boundary interval and early Lochkovian limestones, the Silurian-Devonian boundary occurs just above base of limestone sequence. $\bullet$ D - bed No. 6 , middle part of Požáry Formation, mudstone with thin beds of skeletal limestones above hardgrounds and erosive surfaces. • E, G - bed No. 28, Požáry Formation, Přídolí, late $M$. transgrediens Zone, cephalopod limestone overlaying erosive surface in mudstone. • F, I - bed No. 23, Požáry Formation, Přídolí, late M. transgrediens Zone, coarse crinoidal limestone interbedded with thin mudstone beds. • H - bed No. 17, Požáry Formation, Přídolí, M. transgrediens Zone, cephalopod accumulation with small intraclasts (cross bedded packstone) filling bottom depression above erosive surface. - J - bed No. 46, lowermost part of Lochkov Formation, earlier M. uniformis Zone, lower bedding plane of skeletal limestone with numerous well oriented shells of Pseudocycloceras sp. $\bullet \mathrm{K}$ - bed No. 54, middle part of Lochkov Formation, late M. uniformis Zone, upper bedding plane of mudstone with Pseudocycloceras sp. 


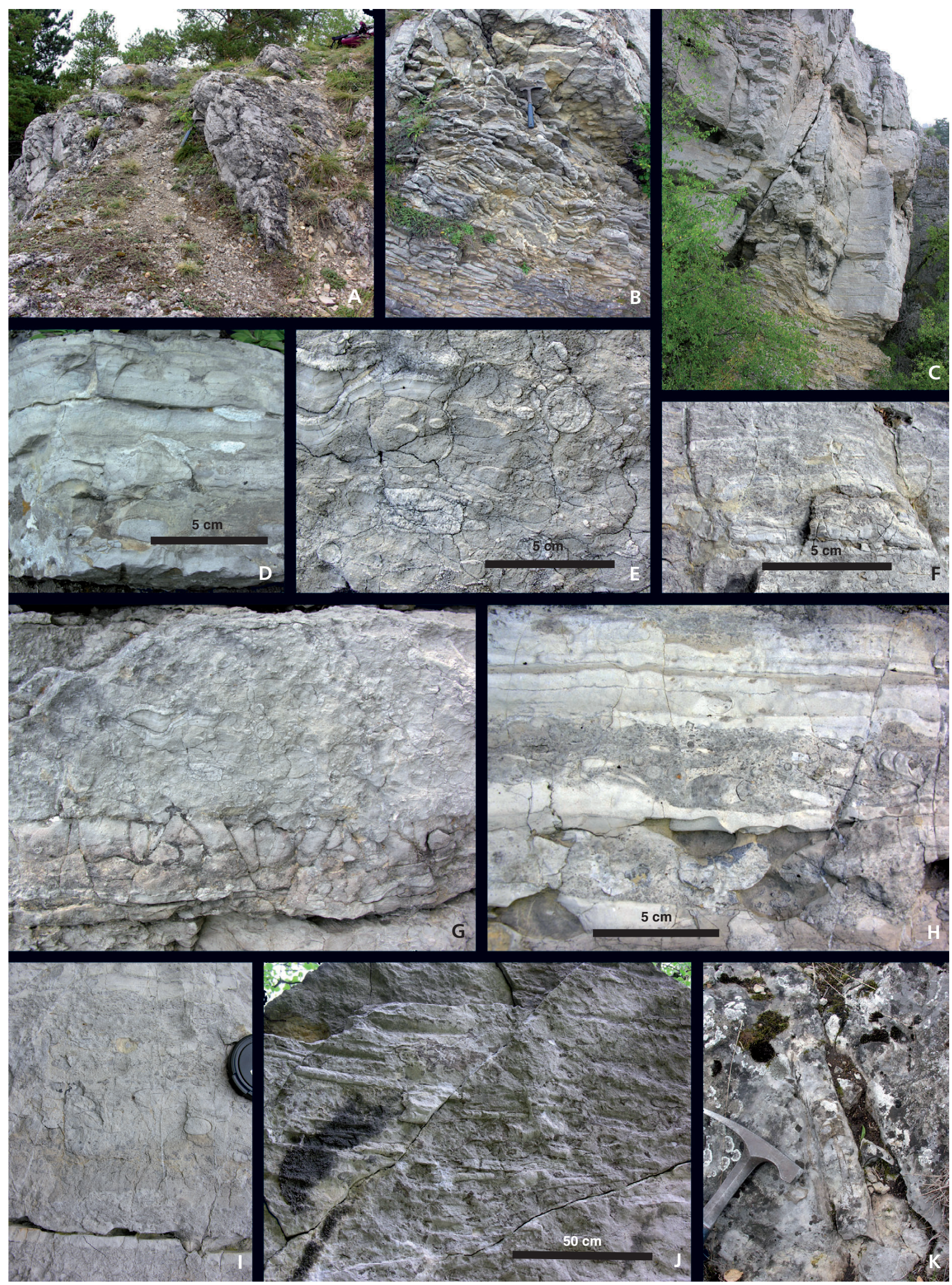


was for a long time considered to be an orthocerid (Sweet 1964, Marek 1971, see discussion in Manda 2001).

The rate of change in shell morphology throughout ontogeny is relatively high and the majority of these nektobenthic species have relatively short stratigraphic range. Most genera of nektobenthic orthocerids are cosmopolitan (in the temperate to tropical zones), but individual species are usually endemic.

\section{Nektobenthic early stage with nektic-nektobenthic adults (Pseudorthocerida)}

A unique combination of shell characters such as a cup-shaped apex with a cicatrix (as in the Nautiloidea) and a longiconic shell with cameral and intrasiphonal deposits (Barskov 1963) characterise members of this group, the pseudorthoceratids. The representatives of this group are large Silurian cephalopods with the maximal shell diameter so far recorded being $18 \mathrm{~cm}$, and with the shell length reaching $150 \mathrm{~cm}$. Members of the pseudorthoceratid family Geisonoceratidae had a large straight or slightly curved longiconic shell with a straight and oblique aperture. The cameral-intrasiphonal deposits are well developed. Shell diameter is typically about $5 \mathrm{~cm}$, but shells with $15 \mathrm{~cm}$ diameter are known from some species. Gnoli (1987) interpreted the geisonoceratids as living close to the bottom (Gnoli 1987). They occur especially in limestone facies and less commonly in shales. The geisonoceratids are known since the Ordovician but are rather rare cephalopods in Př́dolí and Early Devonian strata.

A very unusual shell ontogeny was documented in the common pseudorthocerid genus Pseudocycloceras, which developed three disctinct ontogenetic stages. The first stage is characterised by a straight shell having regular oblique growth lines, low phragmocone chambers, a relatively thin siphuncle, and a shallow hyponomic sinus. The maximal diameter of this growth stage varies between 3 to $5 \mathrm{~mm}$. The second stage of shell ontogeny is characterised by a slightly endogastrically curved shell with well-developed annulations, longer phragmocone chambers, and cameral deposits. Maximal shell diameter in this stage varies from 8 to $15 \mathrm{~mm}$. A straight shell, irregular or missing growth lines and very long phragmocone chambers characterize the third stage again. Maximal shell diameter in this stage is about $180 \mathrm{~mm}$. According to Flower (1957) and Gnoli (1987), all of the above-mentioned stages were probably nektobenthic with the shell orientated horizontally (cameral deposits); the distinct hyponomic sinus indicates active swimming and jet propulsion. Shells of the first and early-late second stages occur in shallow water facies. Third stage shells occur in shallow (limestone) as well as deeper water sediments (mudstone and shale). Adult animals thus migrated apparently from shallow water areas to the deeper water areas.
Lyecoceras and allied genera represent another form of pseudorthocerids included in this group. Their shell is longiconic, slightly curved and endogastric, the body chamber is short, and the aperture is frequently modified (weak constriction, protruding hyponomic sinus). The shell surface is smooth or, more frequently, with highly elaborated sculpture (radial-transversal ribs). Cameral deposits are reduced and the phragmocone chambers bear characteristic oblique sutures with lateral lobes. Unlike other pseudorthoceratids, their shells were orientated vertically during their adult life (reduced cameral deposits, inclination in suture). A well-developed hyponomic sinus and relatively short body chamber suggest active swimming and good buoyancy control (Mutvei 1957). Their occurrences in shallow water facies suggests that this genus preferred shallow water environments.

\section{Nektobenthic early stage and nektobenthic-benthic adult (Actinoceratoidea)}

Actinoceratids comprise cephalopods with a relatively long, usually large, straight shell. The large embryonic shell bears a large caecum (initiation of siphuncle). The siphonal tube is thick with intrasiphonal deposits forming complicated system of tubes. Cameral deposits may also be present in some species. Teichert $(1933,1964)$ suggested that actinoceratids were probably poor swimmers living very close to the bottom, similarly to endoceratids. In some Silurian and Devonian taxa, the siphonal deposits and thickness of the siphuncle may be reduced during shell growth (e.g., Niko 1998). Actinoceratids especially inhabited warm-water carbonate platforms. Actinocerid cephalopods have been interpreted as indicators of tropical and temperate water masses (Flower 1957), but some actinocerids are also known from higher latitudes (Serpagli \& Gnoli 1977, Kröger 2008). The actinoceratids are rare in the Wenlock and Ludlow strata of Bohemia, but in the Přídolí, their diversity distinctly increased, but only one species is known from the Lochkovian. The abundance of actinoceratoids in Bohemia is very low, they were found in relatively deep water limestone and shale intercalated with mudstone.

\section{Benthic early stage with nektobenthic adult (Nautiloidea)}

The demersal nautiloids (Oncocerida and Discosorida) consist of cephalopods with longiconic cyrtoconic shells and typically with breviconic shells (straight or slightly curved). Variability in shell form is high. Demersal nautiloids have a large shell apex with a cicatrix and the aperture is usually modified (constriction) during life, aperture was oriented downward or foreward. A typical feature of this group is the very high rate of morphological change in the 
shell throughout ontogeny. The vast majority of its species have very short stratigraphic ranges. Adaptive radiations of demersal nautiloids are documented after some Silurian extinction events (unpublished data). Species of this group are usually restricted to a small geographic area (one basin), but there are many shared taxa between Bohemia and Gotland (Stridsberg 1985, Manda 2008).

Members of the family Oonoceratidae are characterised by having a slender, curved exogastric shell, a thin and marginal siphuncle, and a short body chamber (Manda \& Turek 2009b). In life position, their aperture was slightly oblique to the bottom, they were probably slow swimming cephalopods, living close to the bottom (i.e. demersal; compare Westermann 1998).

Members of the family Oocerinidae are morphologicaly convergent with the Oonoceratidae, but their siphuncle is thicker with lamellar, intrasiphonal deposits (Zhuravleva 1974, Manda 2001). Furthermore, the Mandaloceratidae have a straight or slightly curved breviconic shell and their aperture is constricted just before the end of shell growth (Flower \& Teichert 1957). The balloonshaped shells of the mandaloceratids with contracted apertures suggest that they lived close to the bottom with a downward orientated aperture (Holland 1984).

The family Hemiphragmoceratidae includes, as in the Mandaloceratidae, nautiloids with a breviconic shell and constricted aperture, but their shell is curved and endogastric. The aperture is very complex, having 2-8 lobes. Their siphuncle is relatively thick with lamellar deposits. These morphological features suggest that hemiphragmoceratids were better swimmers than mandaloceratids, but lived close to the bottom as previously suggested by Stridsberg (1985).

The Rizosceratidae form a group of oncocerids with a short, straight or slightly curved breviconic shell with an unconstricted (endogastric as well as exogastric). Their body chamber is short and their siphuncle very thin and marginal. Intrasiphonal deposits are unknown in rizosceratids. The shell apex is straight and spherical with a cicatrix (its diameter varies in individual species between 2 to $6 \mathrm{~mm}$ ). Shell length at hatching stage does not exceed 8 to $10 \mathrm{~mm}$ (unpublished data). Rizosceratids lived close to the bottom with the aperture orientated downward (species with straight shells) or obliquely to the bottom (species with curved shells).

\section{Benthic early stage with nektonic adult (Nautioidea)}

Tarphyceratids and oncocerids with coiled shells were placed in this group. The apex of their shells is relatively large, cup-like and bearing a cicatrix. The embryonic shell diameter is greater than $3 \mathrm{~mm}$ (Turek 2010). Early posthatching specimens lived close to the bottom, however, a distinct hyponomic sinus was developed at the completion of one or two whorls. This morphologic feature suggests a transition from a benthic to a more active nektonic mode of life. In adult animals, the aperture was orientated anteriorly. The best-known example represents the genus Boionautilus, having a shell strongly resembling the presentday Nautilus (Turek 2008). Coiled shells also appeared in some lineages of oncocerids. The Oxygonioceratidae have a narrowly coiled and laterally compressed shell with a ventral keel and a ventral marginal siphuncle (Chen et al. 1981). In contrast, the Naedyceratidae include oncocerids with a widely (depressed) coiled shell. Their siphuncle is also ventrally situated, but its diameter is greater. Lamellar intrasiphonal deposits were also documented in this group (Manda 2001). Coiled exogastric shells with few whorls (1-4) and a thin marginal siphuncle were also described in some Oonoceratidae (e.g. Eurizoscerina; Manda \& Turek 2009c).

\section{Results}

\section{Carbon isotope record}

\section{The Zadní Kopanina Section}

Carbon isotope sampling began in the Požáry Formation about $12 \mathrm{~m}$ below the Silurian-Devonian boundary and about $1.3 \mathrm{~m}$ below the FAD of Monograptus bouceki. The last sample was collected about $6 \mathrm{~m}$ above the Silurian-Devonian boundary. In total, 39 samples were analysed for $\delta^{13} \mathrm{C}$ content, 23 samples were taken from the Silurian part of the section and 16 samples from the Early Devonian Lochkov Formation. The $\delta^{13} \mathrm{C}$ values increase from $-0.3 \%$ in the oldest sample (Time slice $\mathrm{C}-1.3 \mathrm{~m}$ below the FAD of Monograptus bouceki) to values of about $+2 \%$ in the middle of Time slice E (FAD Dayia bohemica to LAD Monograptus transgrediens). $\delta^{13} \mathrm{C}$ values began to increase rapidly from the middle of Time slice $\mathrm{E}$ to its end, at which point the maximum $\delta^{13} \mathrm{C}$ value $(+3.42 \%$ ) for the Silurian part of the Zadní Kopanina Section was recorded. The following interval, slice F (LAD Monograptus transgrediens to FAD Monograptus uniformis) is relatively thin. Two samples analysed from this time slice show a reduction in $\delta^{13} \mathrm{C}$ values, down to about $+2.2 \%$. This trend changed in the first Devonian samples (Time slice $\mathrm{G}$, FAD Monograptus uniformis to FAD M. hercynicus), which revealed a continuous increase in $\delta^{13} \mathrm{C}$ values, to $+3.6 \%$ at about $95 \mathrm{~cm}$ above the Silurian-Devonian boundary. Further upward, in Time slice $\mathrm{G}$, the $\delta^{13} \mathrm{C}$ values gradually decreased to about $+1.1 \%$ at the end of the time slice. The last four samples from Time slice H (above FAD $M$. hercynicus) again showed some increase, rising to $+2.7 \%$ and then a decrease to $+1.1 \%$ o. 


\section{The Opařilka Section}

The first carbon isotope sample was taken from the upper beds of Time slice $\mathrm{C}$ in the Požáry Formation, about $19.8 \mathrm{~m}$ below the Silurian-Devonian boundary and about $1.6 \mathrm{~m}$ below the FAD of Monograptus bouceki. The last sample was collected about $5.2 \mathrm{~m}$ above the Silurian-Devonian boundary, at a level where the Opařilka Section ends. From the Silurian part of the section, 40 samples were analysed for $\delta^{13} \mathrm{C}$ content and 11 samples were analysed from the Early Devonian Lochkov Formation. Similarly to the Zadní Kopanina Section, $\delta^{13} \mathrm{C}$ values gradually increased from $-0.24 \%$ in the oldest sample (Time slice $\mathrm{C}-1.6 \mathrm{~m}$ below the FAD of Monograptus bouceki) to values of about $+2.3 \%$ at the end of Time slice D (FAD of Monograptus bouceki to FAD Dayia bohemica). $\delta^{13} \mathrm{C}$ values in Time slice E (FAD Dayia bohemica to LAD Monograptus transgrediens) were scattered, reaching the highest $\delta^{13} \mathrm{C}$ value $(+3.2 \%)$ close to the end of Time slice E. The following Time slice F (LAD Monograptus transgrediens to FAD Monograptus uniformis) is characterised by high fluctuations in $\delta^{13} \mathrm{C}$ values. Eight samples measured from Time slice $\mathrm{F}$ range from $+2.1 \%$ o to $+4.3 \%$ o. Except for one sample, the remaining ten $\delta^{13} \mathrm{C}$ values from the Devonian (Time slice G, FAD Monograptus uniformis to FAD M. hercynicus) show less fluctuation (from $+2.3 \%$ to $+3.2 \%$ ) than samples from the last Silurian time slice.

\section{The Bílá skála Section}

From the Bílá skála Section, 39 samples were analysed for $\delta^{13} \mathrm{C}$ content (27 samples from the Silurian part of the section and 12 samples from the Early Devonian Lochkov Formation). Sampling began in the Požáry Formation, $11 \mathrm{~m}$ below the Silurian-Devonian boundary and about $0.5 \mathrm{~m}$ below FAD of Monograptus bouceki and ended $7.75 \mathrm{~m}$ above the Silurian-Devonian boundary. Only one $\delta^{13} \mathrm{C}$ value was measured in Time slice $\mathrm{C}(0.5 \mathrm{~m}$ below FAD of Monograptus bouceki). Generally, $\delta^{13} \mathrm{C}$ values gradually increased from about $+0.34 \%$ at the beginning of Time slice D to $+2.5 \%$ at the end of Time slice E (from FAD of Monograptus bouceki to LAD Monograptus transgrediens) with two fluctuations (in the middle of Time slices D and E). Six samples measured from the narrow Time slice F (LAD Monograptus transgrediens to FAD Monograptus uniformis) range from $+2.4 \%$ to $+2.8 \%$. The first ten Devonian samples of Time slice G (to a level about $3.5 \mathrm{~m}$ above the Silurian-Devonian boundary) show greater fluctuations (from $+2.3 \%$ to $+3.4 \%$ ) than samples from the last Silurian time slice. The last two values from Time slice $\mathrm{G}$ indicate a decrease in $\delta^{13} \mathrm{C}$ content and only two samples measured from Time slice $\mathrm{H}$ again suggest a rise in $\delta^{13} \mathrm{C}$, similarly as in the Zadní Kopanina Section.

\section{The $\delta^{13} \mathrm{C}$ composite record}

The $\delta^{13} \mathrm{C}$ data from the three studied sections of the carbonate platform of the Prague Basin were combined in one composite record to characterize general trends across the Silurian-Devovian boundary of the Prague region. Isotope data were grouped into the time slices used for biodiversity analysis of cephalopods. Such grouping resulted in a loss in stratigraphic resolution of the $\delta^{13} \mathrm{C}$ signal, but one has to keep in mind that the course of isotopic changes in any study of the fossil record is reconstructed only from discrete values (isotope samples). Thus, no record is completely sampled (i.e., not all carbonate layers were sampled). In addition, in the relatively shallow environment of the carbonate platform, one has to also expect an incomplete rock record (because of possible sedimentary gaps). Grouping of $\delta^{13} \mathrm{C}$ data into one composite record thus characterises the general regional trend in $\delta^{13} \mathrm{C}$ (Fig. 6) and allows for analysis of the relationship between the $\delta^{13} \mathrm{C}$ record and cephalopod biodiversity changes on the same scale.

Comparison of median $\delta^{13} \mathrm{C}$ values from two neighbouring time slices (Fig. 6) revealed a distinct and statistically significant increase in $\delta^{13} \mathrm{C}$ values from Time slice $\mathrm{C}$ to Time slice $\mathrm{F}$ (the last Silurian time slice). On the other hand, there is no statistically significant difference between Time slices F and G, or between G and H. Therefore, our data from the Prague Basin clearly shows that the latest Silurian (Time slice F: LAD Monograptus transgrediens to FAD Monograptus uniformis) was a time when the increase in $\delta^{13} \mathrm{C}$ values reached its maximum and subsequently, in the Early Devonian, is characterized by relatively constant $\delta^{13} \mathrm{C}$ values. The latest Silurian is therefore a time of change in dynamics of the global carbon cycle in the marine ecosystem and the early Lochkovian is characterized by more steady conditions following these changes.

\section{Cephalopod biodiversity}

\section{Total cephalopod species diversity and turnover rates}

Analysis of the cephalopod diversity dataset revealed extremely high species diversity in the Time slices D and E (FAD M. bouceki to LAD M. transgrediens). The total number of cephalopod species reached 97 and 110 in these mid-Přídolí time slices, which is globally the highest recorded cephalopod diversity in the latest Silurian. These values are three times higher than the most diversified Přídolian cephalopod faunas outside the Prague Basin (Tables 2, 3). Except for this peak, the "background" diversity shows a decreasing trend from the late Ludlow to the end of the Lochkovian. The pattern in mean standing diversity (Figs 6, 7) is the same as that in total diversity and thus, 

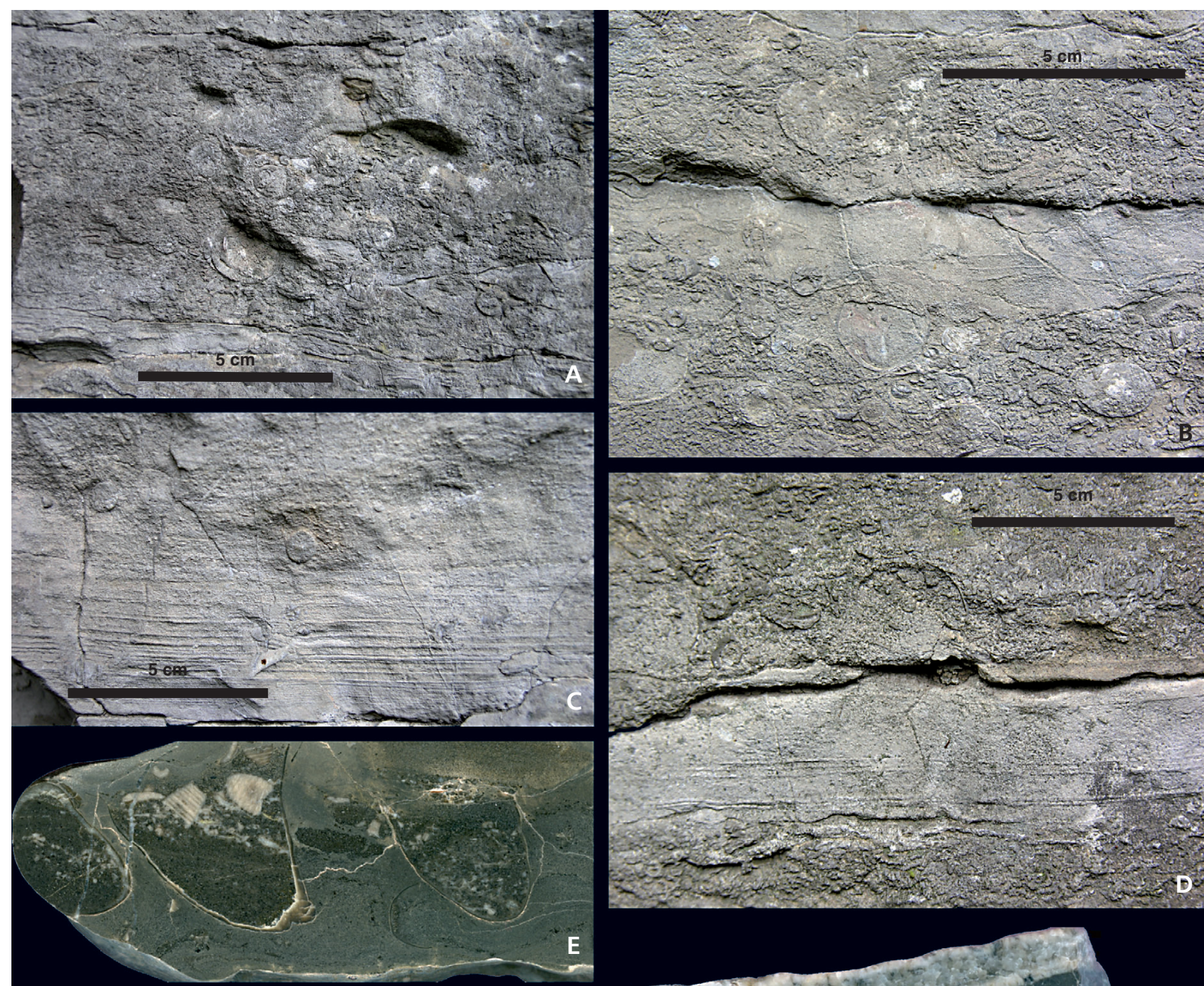

西

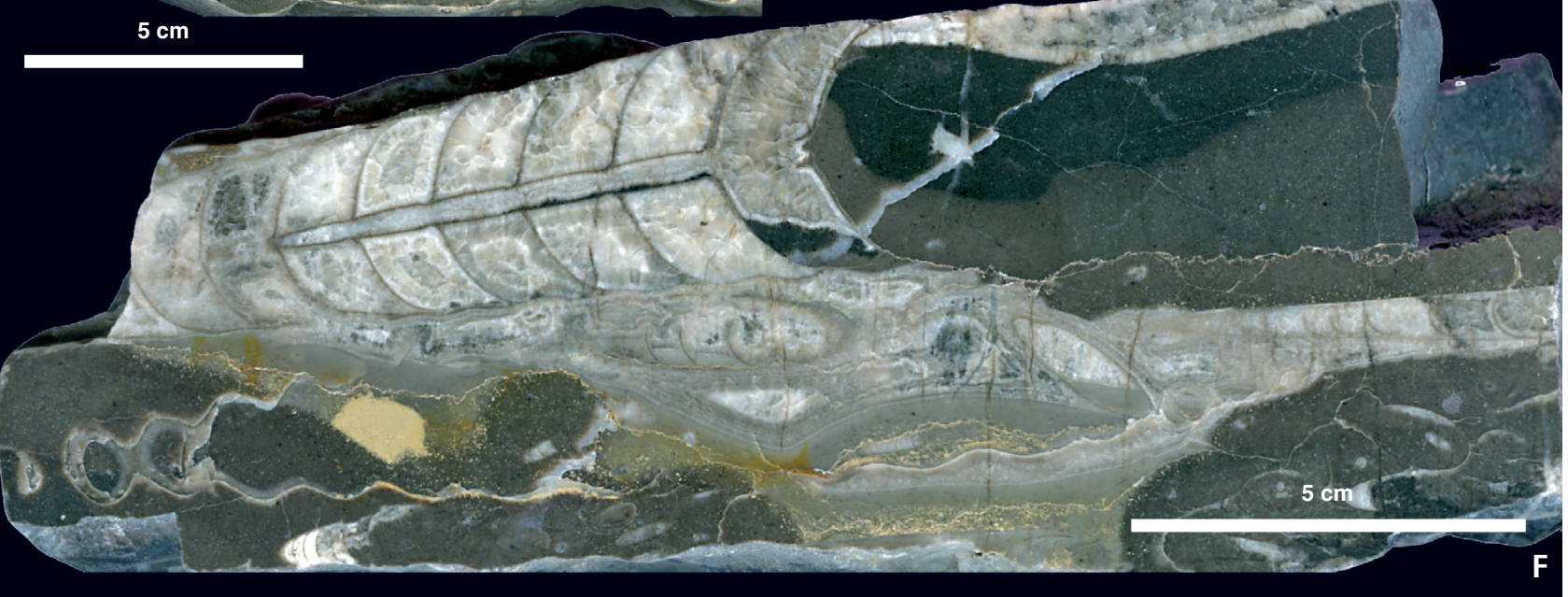

Figure 4. Zadní Kopanina Section, Požáry Formation, Př́ídolí, Monograptus bouceki Zone. • A, B, D - bed No. 13, base of thick cephalopod limestone sequence which consists of up to $15 \mathrm{~cm}$ thick beds of cephalopod cephalopod packstones separated with erosive surfaces and thin beds of mudstones with upper erosive surfaces. $\bullet$ C - bed No. 13 , laminated mudstone with rare crinoid debris passes into cephalopod wackestone. $\bullet$ E - bed No. 10, polished slab of a thin mudstone bed with common large shells of gastropod Orthonychia cf. anguis, gastropod shells are filled with coarse crinoidal debris. $\bullet \mathrm{F}-$ bed No. 13, polished slab of cephalopod limestone with annulated shells of Kopaninoceras fluminese. 
Table 2. Data summarising the diversity of cephalopods in the Př́idolí and Lochkovian. $\mathrm{P}$ - number of species from Přídolí, L - number of species from Lochkovian, SD - number of species from Silurian-Devonian boundary in area where the Přídolí and the Lochkovian are not distinguished. Column B - mean number of species shared with Bohemia. An asterisk designates fauna at which age is determined as Lochkovian-Pragian.

\begin{tabular}{|c|c|c|c|c|c|c|c|}
\hline Area & $\mathrm{P}$ & $\mathrm{B}$ & $\mathrm{L}$ & $\mathrm{B}$ & SD & B & References \\
\hline Liévin, N France & - & - & - & - & 21 & 13 & Gosselet et al. (1912), Barrois et al. (1912) \\
\hline Wales & 5 & 2 & - & - & - & - & Holland (2000) \\
\hline Ebbe Inner, Germany & - & - & - & - & 7 & 5 & Dahmer (1951) \\
\hline Harz, Germany & 16 & 15 & - & - & - & - & Heritsch (1930) \\
\hline Massiv Armorican, France & 3 & 3 & - & - & - & - & Babin (1966), Babin et al. (1979), Křǐž \& Paris (1982) \\
\hline Sardinia & 17 & 16 & 16 & 15 & - & - & Gnoli (1982), Gnoli \& Serpagli (1991) \\
\hline Carnic Alps, Austria & 16 & 15 & - & - & - & - & Bogolepova (1998), Histon (2002) \\
\hline Spain & 3 & 3 & - & - & - & - & Bogolepova et al. (1998) \\
\hline Graz, Austria & 7 & 7 & - & - & - & - & Histon et al. (2010) \\
\hline Morocco & 6 & 4 & 14 & 5 & - & - & Kröger (2008) \\
\hline S of Gotland (Beyrichien Kalk) & 7 & 4 & - & - & - & - & Krause (1877), Dzik (1984), Dzik \& Kiselev (1985) \\
\hline Poland & 2 & 2 & - & - & - & - & Dzik (1984) \\
\hline Estonia & 16 & 5 & - & - & - & - & Saldzius (1966), Kiselev et al. (1990) \\
\hline Podolia & 8 & 3 & $16^{*}$ & 1 & - & - & Kiselev et al. (1987), Zhuravleva $(1972,1974,1978)$ \\
\hline Caucaus Mts & - & - & - & - & 7 & 7 & Janisechevskij (1917) \\
\hline North Urals & 25 & 23 & 15 & 10 & - & - & Kiselev (1984) \\
\hline Tian-Shan & 35 & 15 & 31 & 19 & - & - & Kiselev et al. (1993) \\
\hline Japan & - & - & 9 & 0 & - & - & Niko $(1996,1998,2003)$ \\
\hline
\end{tabular}

Table 3. Similarity in cephalopod faunas between Time slices A-H (latest Ludlow-late Lochkovian).

\begin{tabular}{|c|c|c|c|c|c|c|c|c|}
\hline DICE/Jaccard & Time slice A & Time slice B & Time slice $\mathrm{C}$ & Time slice D & Time slice E & Time slice F & Time slice G & Time slice $\mathrm{H}$ \\
\hline Time slice A & - & 0.53 & 0.24 & 0.13 & 0.11 & 0.09 & 0.05 & 0.02 \\
\hline Time slice B & 0.70 & - & 0.42 & 0.20 & 0.17 & 0.10 & 0.05 & 0.03 \\
\hline Time slice C & 0.39 & 0.60 & - & 0.32 & 0.27 & 0.27 & 0.07 & 0.04 \\
\hline Time slice D & 0.23 & 0.33 & 0.48 & - & 0.86 & 0.18 & 0.05 & 0.02 \\
\hline Time slice E & 0.20 & 0.29 & 0.43 & 0.93 & - & 0.17 & 0.05 & 0.02 \\
\hline Time slice F & 0.17 & 0.19 & 0.42 & 0.31 & 0.29 & - & 0.17 & 0.07 \\
\hline Time slice $\mathrm{G}$ & 0.09 & 0.10 & 0.14 & 0.10 & 0.09 & 0.29 & - & 0.27 \\
\hline Time slice $\mathrm{H}$ & 0.05 & 0.05 & 0.07 & 0.03 & 0.03 & 0.13 & 0.42 & - \\
\hline
\end{tabular}

the rapid increase in cephalopod diversity pattern in the Time slices D and E appears to be a real feature and not an artefact caused by the different durations of time slices used for the diversity analysis or by the high number of singletons.

The relative origination rate value varies considerably across the analysed period (Fig. 6). During the Přídolí, the relative origination rate is below 0.25 , with the exception of Time slice D. Almost $70 \%$ of the recorded cephalopod species originated during this time slice (Figs 6, 7). The early Lochkovian had the highest relative origination rate value, which reached $0.75 \%$. Similarly, the relative origination rate is also high during the late Lochkovian. Taken together, the analysed data revealed two periods of rapid origination of new cephalopod species, the first during the period between the FAD of $M$. bouceki and that of Dayia bohemica and the second during the Lochkovian.

Relative extinction rate values also vary considerably during the analysed period (Figs 6,7). They are relatively high at the beginning of the Prídolí from Time slice $\mathrm{E}$ to the end of the Lochkovian; in Time slice B, the extinction rate amounted to 0.53 , i.e., about half of the recorded cephalopod species. The highest value for relative extinction rate occurs in Time slice E, which is the time slice with the highest cephalopod species diversity with 110 recorded species. Before the end of Time slice E (i.e., before LAD Monograptus transgrediens), more than 80 percent of all recorded cephalopod species became extinct. A comparison of origination and extinction rates within each analysed time slice revealed some additional information. For that 
Figure 5. Diagram showing main cephalopod strategies and distribution of adults in relation to facies. Abbreviations of facies: F1 - cross-bedded fine-grained grainstone, F2 - brachiopod packstone and grainstone, F3 - thin bedded crinoidal pack-grainstone, F4 - cephalopod grain-packstone, F5 - cephalopod wacke-mudstone, F6 - wacke-mudstone intercalated with shale, F7 - laminated shale.

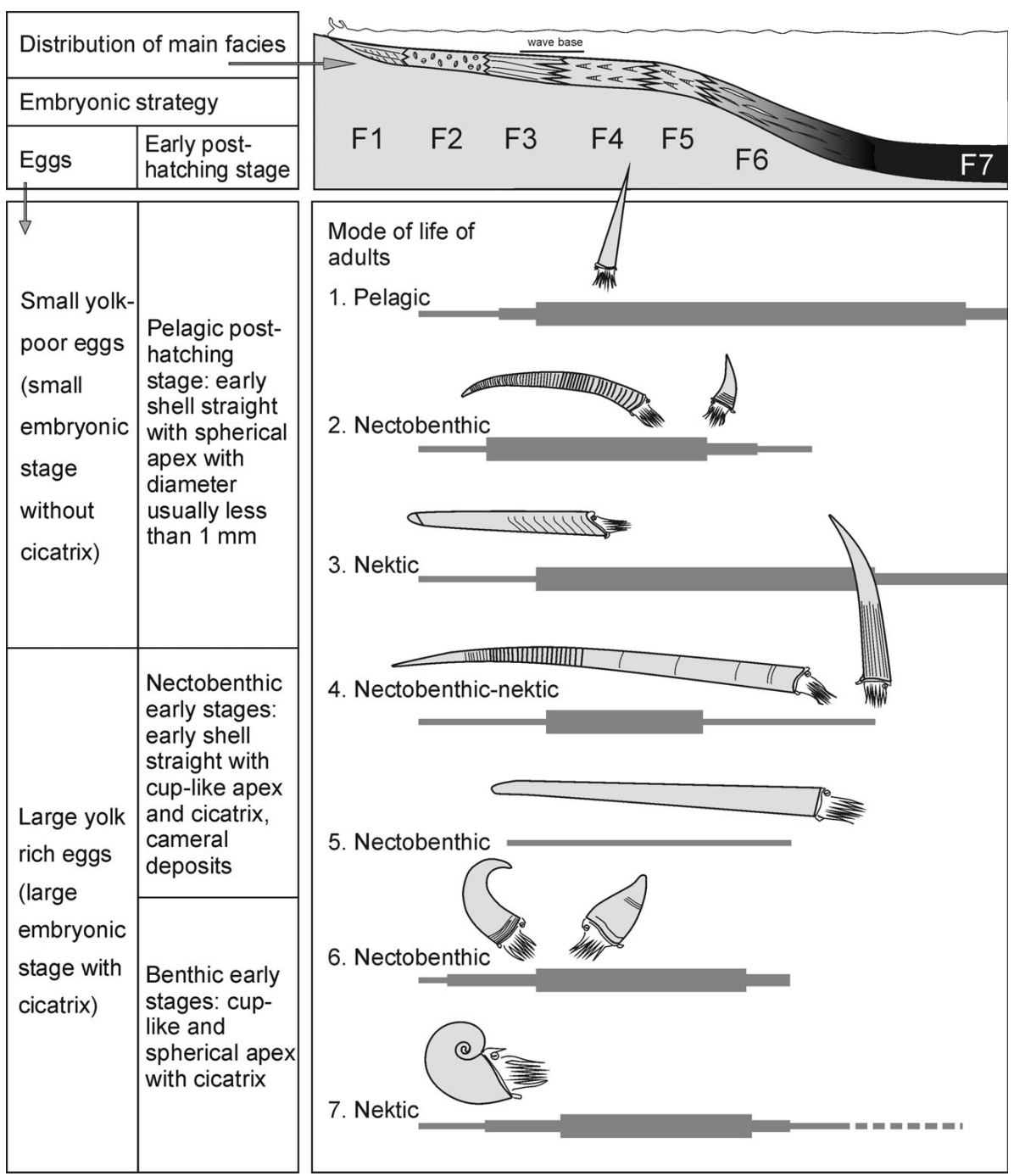

slightly increased during the Time slices D and E (Fig. 8). The number of Tarphycerida and Ascocerida species shows distinctly decreasing trends. However, the latter order has a generally low diversity. By contrast, the diversity of species belonging to the orders Discosorida, Oncocerida, and Actinocerida considerably increased during the Time slices D and E (Fig. 8).

Analysis of the changes in relative abundance in cephalopod orders in individual time slices revealed another pattern. Members of the Discosorida and Oncocerida form a dominant part of cephalopod faunas from the late Ludlow. From the FAD of Monograptus lochkoviensis to LAD of Monograptus transgrediens (Time slices C-E), about $60 \%$ of all cephalopod species belong to one of these two orders. This diversity pattern changes dramatically from the beginning of time slice $\mathrm{F}$ (i.e. since LAD Monograptus transgrediens), when the relative abundance of discosorid and oncoceratid cephalopod species dramatically decreased to 0 and $14 \%$, respectively. In the subsequent time slices $\mathrm{G}$ and $\mathrm{H}$ (Lochkovian), members of the 


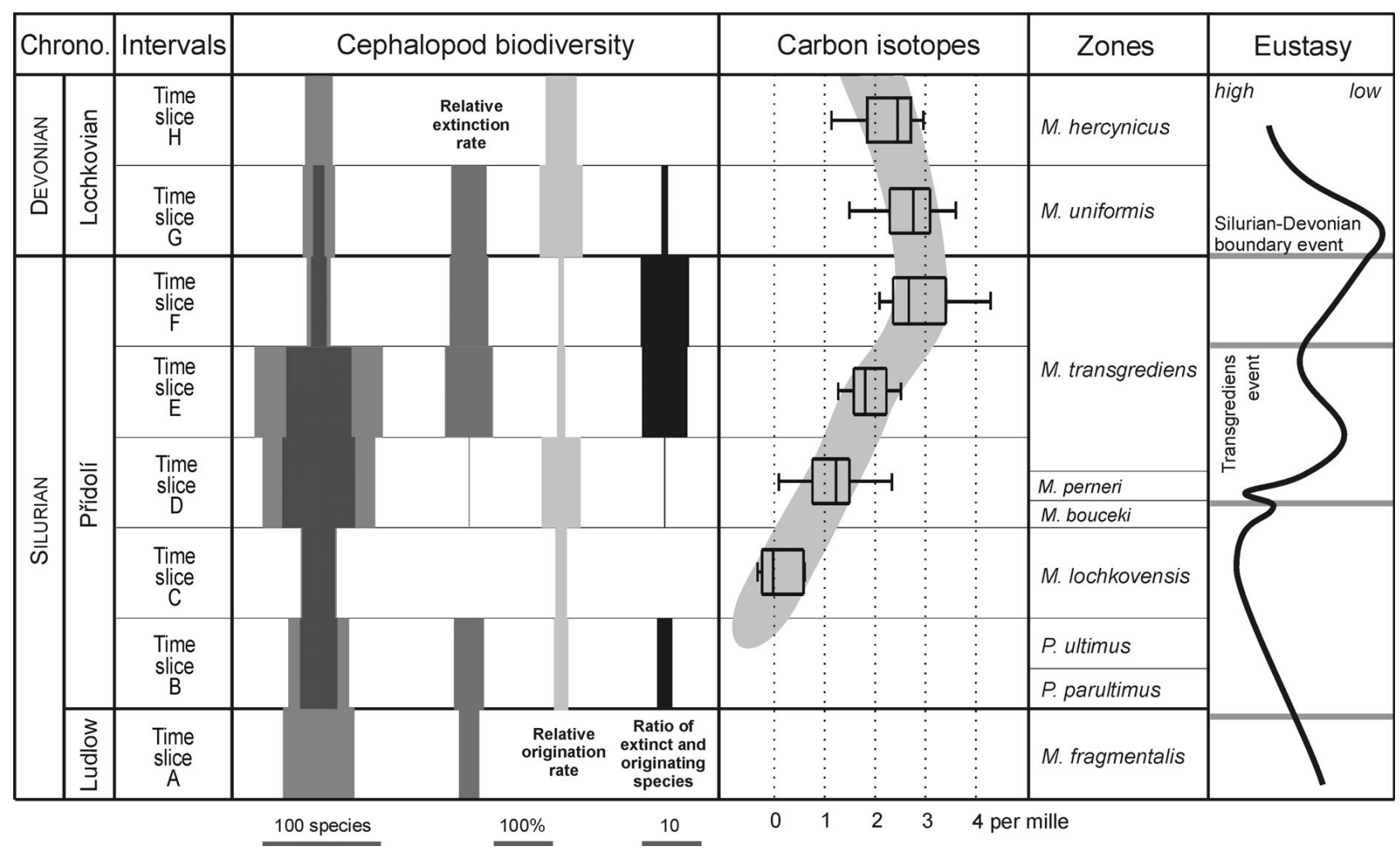

Figure 6. Cephalopod biodiversity, carbon isotopes, biostratigraphy and assumed eustatic curve in the latest Ludlow, Př́idolí and Lochkovian of the Prague Basin.

Discosorida and Oncocerida together contain less than $30 \%$ of the total cephalopod fauna (Fig. 8). By contrast, the relative abundance of orthoceratids and pseudorthoceratids, which contained less $40 \%$ of all cephalopod species from the late Ludlow to LAD Monograptus transgrediens (end of Time slice E), greatly increased in the lastest Silurian and in the Lochkovian. Just before the LAD of Monograptus transgrediens (during time slice E), the relative abundance of orthoceratids and pseudorthoceratids was $24 \%$. However, during the latest Silurian (Time slice F), orthoceratids and pseudorthoceratids contained $76 \%$ of all cephalopods. This large statistically significant increase in their relative abundance is not related to an increase in their total diversity but to a distinct decrease in total species diversity in other cephalopod orders (Figs 7,8). Taken together, the boundary between intervals $\mathrm{E}$ and $\mathrm{F}$ represents a time when the most intense change in cephalopod order composition for the period from the late Ludlow to the end of the Lochkovian occurred. Therefore, it appears like the orthoceratids ended the incumbency of the previously dominating groups such as the discosorids and oncocerids.

\section{Faunal similarity}

The Jaccard and Dice association similarity indices were calculated in order to characterise faunal similarity in cephalopod faunas for individual time slices. The highest similarity coefficients occur always in stratigraphically neighbouring time slices (Table 3). This means that similarity of cephalopod faunas depends on time and was controlled by relatively rapid cephalopod evolution from the late Ludlow to the end of the Lochkovian. Thus, observed changes in species-level composition of the cephalopod faunas across this time period of about $10 \mathrm{Ma}$ are related mainly to cephalopod evolution and not to changes in other environmental parameters (e.g. facies changes). Our analysis revealed that the closest faunal affinity is between cephalopod faunas of Time slices D and E (Dice similarity coefficient equal to 0.93 ).

A cluster analysis produced dendrograms displaying the same branching topology for both the Jaccard and Dice indices and both clustering modes. The only differences exist in the similarity values and therefore, only a dendrogram based on clustering of the measured Dice distance is figured (Fig. 9). The Dice measure puts more weight on joint occurrences than does the Jaccard coefficient. The constrained dendrogram also shows two relatively well-separated clusters (Fig. 9). The first cluster unites the Silurian cephalopod faunas (Time slice A-F) and the second cluster unites cephalopod faunas from the two Devonian Time slices ( $\mathrm{G}$ and $\mathrm{H})$. 

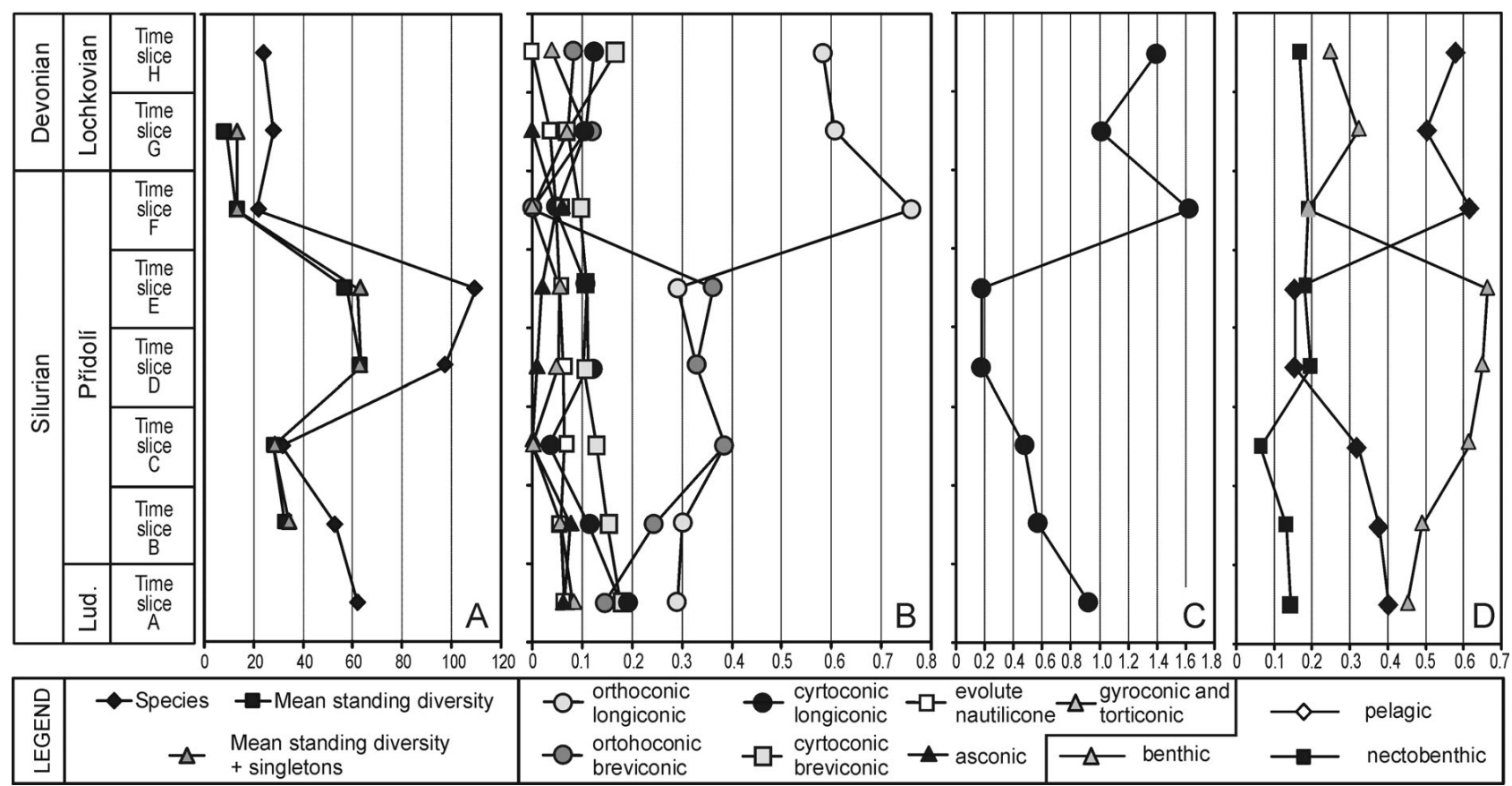

Figure 7. Comparison of cephalopod diversity versus morphotypes and strategies in the latest Ludlow-late Lochkovian. $\bullet$ A - simple diversity, mean standing diversity and mean standing diversity plus singletons. $\bullet \mathrm{B}$ - relative diversity of morphotypes. $\bullet \mathrm{C}-$ ratio between cephalopods with small and large embryonic shell. $\bullet \mathrm{D}$ - relative diversity of cephalopods with benthic, nektobenthic and pelagic early stages.

\section{Analysis of relative abundance of shell morphotype}

Late Ludlow-Lochkovian cephalopod faunas consist of species belonging to seven cephalopod orders (Fig. 5), generally differing in the morphology of their shells. However, in some orders, there are more than one morphologic type and additionally some morphologic types may occur in more than one order. Therefore, distribution of morphologic types among late Ludlow-Lochkovian cephalopods is not exactly identical with their order-level taxonomy. Morphological disparity within these cephalopods is very high and for the selected analysis, we grouped them into seven morphological categories (Fig. 7).

Analysis of changes in the prefered morphologic shell types for the period from the late Ludlow to the end of the Lochkovian revealed relatively the low frequency of five shell morphologies (CL, EN, CB, GT, and AS; see Fig. 7). The frequency of cephalopod species with the latter shell type is generally about or below 10 percent. By contrast, cephalopods with longiconic and breviconic orthoconic shells were a dominant part of the cephalopod faunas since the beginning of the Prídolí (FAD of Pristiograptus parultimus). Since the FAD of Monograptus lochkoviensis (beginning of Time slice C) to that of Monograptus transgrediens (end of Time slice $\mathrm{E}$ ), the number of cephalopod species with orthoconic shells was greater than 65 percent of all recorded cephalopod species. The transi- tion from Time slice $\mathrm{E}$ to $\mathrm{F}$ is connected with the most prominent changes in relative abundance of shell morphologic types for the entire period analysed (late Ludlow-Lochkovian). None of the cephalopod species with an orthoconic breviconic shell occurred in the latest Silurian (Time slice F), even though these species formed more than one third of the cephalopod fauna in several preceeding time slices (Fig. 7). During the Lochkovian, the frequency of cephalopod species with an orthoconic breviconic shell was lower than $10 \%$.

In contrast, the frequency of cephalopod species with an orthoconic longiconic shell dramatically increased from about 30 (Time slice E) to $76 \%$ in the latest Silurian (Time slice F). The vast majority of latest Silurian cephalopod species thus had orthoconic longiconic shells (Fig. 7). During the subsequent Lochkovian (Time slices $\mathrm{G}$ and $\mathrm{H}$ ), this shell morphology dominated among the cephalopods.

\section{Analysis of changes in cephalopod life strategies}

Three different characteristics of cephalopod species were included in our analysis: size of embryonic shell, juvenile mode of life, and adult mode of life. Relative frequency of embryonic shell size was simply calculated as the ratio of small embryonic to large embryonic shells (Fig. 7). Our analysis revealed a systematic decrease in this ratio from the late Ludlow to Time slice E. In the late Ludlow, the 


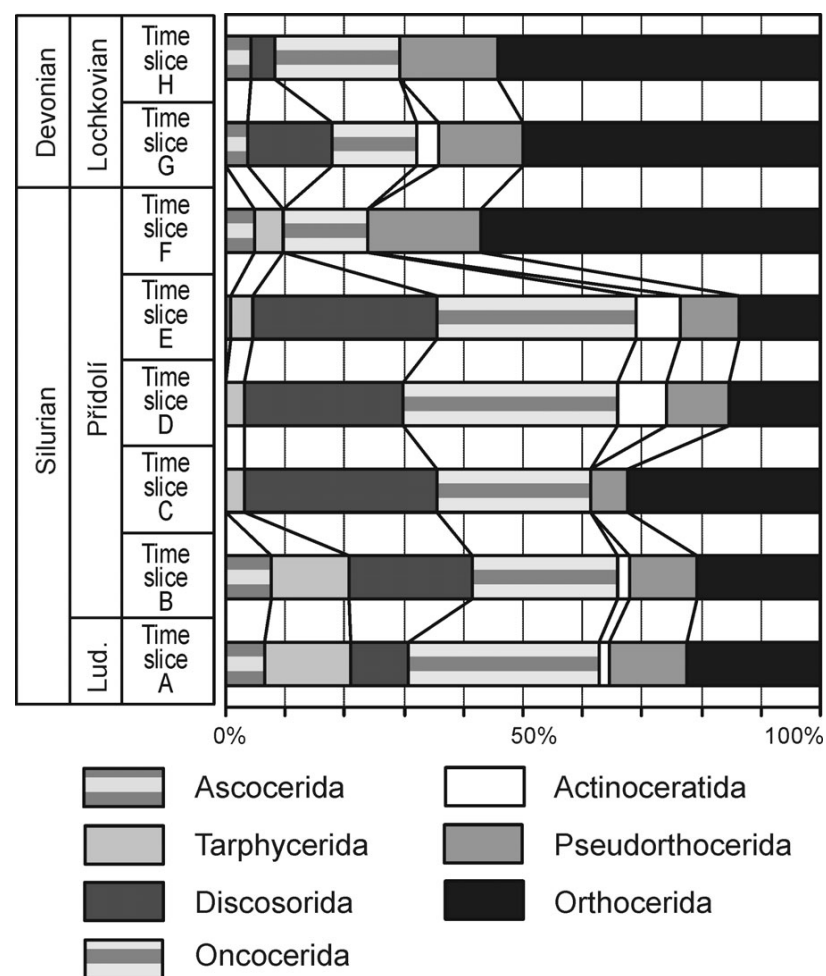

Figure 8. Diversity of cephalopod orders from the latest Ludlow to late Lochkovian.

number of cephalopod species having a small embryonic shell roughly equals the number of cephalopod species having a large embryonic shell. However, cephalopod species with a small embryonic shell formed less than $20 \%$ of all recorded cephalopod species during the period from the beginning of Time slice $\mathrm{D}$ to the end of Time slice $\mathrm{E}$ (i.e., since FAD Monograptus bouceki to LAD Monograptus transgrediens). This pattern changed dramatically during the following time slices $(\mathrm{F}-\mathrm{H})$, when species with a small embryonic shell became dominant (more than $60 \%$ of cephalopod species during the latest Silurian belong to this group; see Fig. 7C). The transition from Time slice $\mathrm{E}$ to $\mathrm{F}$ corresponds with the most prominent change in the relative abundance of small embryonic shells during the entire analysed period (late Ludlow-Lochkovian).

The late Ludlow-Lochkovian cephalopods can be placed in one of the three groups (i.e. demersal, nektobenthic, and pelagic) according to their early life strategy (see above). A nektobenthic mode of life was the least frequent strategy for the late Ludlow-Lochkovian juvenile cephalopods. Relative frequency of this mode of life varies between 13 and $20 \%$ of all species present with only one exception, the period between the FAD of Monograptus lochkoviensis and that of Monograptus bouceki (Time slice C), when cephalopod species with juveniles exhibiting a nektobenthic mode of life formed only about $6 \%$ of the cephalopod fauna. By contrast, relative frequency of species with a demersal juvenile life strategy systematically increased from $45 \%$ in the late Ludlow, to $65 \%$ in of the cephalopod fauna Time slice E. However, their relative abundance rapidly decreased to less than $20 \%$ at the beginning of Time slice F (latest Silurian) and during the whole Lochkovian, it never again rose to the mid-Přídolí level (Figs 8, 10). The relative abundance of cephalopod species with a pelagic juvenile mode of life shows the opposite trend to that of cephalopod species with a demersal juvenile life strategy. Relative abundace of juvenile cephalopod species with a pelagic strategy systematically decreased from $40 \%$ in the late Ludlow to $15 \%$ in Time slices $\mathrm{D}$ and $\mathrm{E}$. Their relative abundance greatly increased to more than $60 \%$ at the beginning of Time slice F (latest Silurian) and during the subsequent Lochkovian, this juvenile strategy dominated (Figure 10). The transition from Time slice $\mathrm{E}$ to $\mathrm{F}$ is thus connected with the most prominent change in relative abundance of pelagic juvenile live strategy for the entire analysed period (late Ludlow-Lochkovian).

Analysis of adult strategies in cephalopod species revealed a similar pattern. All of the 197 late Ludlow-Lochkovian species can be classified into one of three groups (i.e. nektobenthic, nektonic, and pelagic). Our analysis clearly showed that the nektobethic adult strategy dominated in the late Ludlow-Lochkovian cephalopod species (Fig. 10) with the nektonic and pelagic adult strategy being less frequent. As in the case of juvenile strategies, the most prominent change in adult strategy occurred at the transition from Time slice E to F. Adult cephalopods with a pelagic strategy formed less than $10 \%$ of all cephalopod species during Time slice E. However during the subsequent Time slice F (latest Silurian), the relative abundance of this adult strategy greatly increased to more than $40 \%$ (Fig. 10).

\section{Discussion}

\section{Cephalopod biodiversity}

Analysis of the cephalopod dataset revealed several features of diversity evolution in the Silurain and Early Devonian. The total number of the cephalopod species from the Barrandian included in our analysis represents the majority of all known cephalopod species of this time frame globally and therefore, the results of the analysis also have a global relevance. Our results showed that the faunal similarity of time slices A-H was mainly controlled by the relatively rapid cephalopod evolution in the studied period. Thus, these changes in species-level composition of the cephalopod faunas are rather related to evolutionary changes than to changes in other parameters (i.e., environmental changes). 
The most distinct changes in the period from the late Ludlow to the end of the Lochkovian occurred between Time slices E and F (i.e. around the LAD of Monograptus transgrediens). At the transition from Time slice $\mathrm{E}$ to $\mathrm{F}$, cephalopod species diversity decreased to a fifth of the original number. At the same time, the most distinct changes occurred in cephalopod order composition and in relative abundance of the basic types of embryonic, juvenile, as well as adult life strategies (Fig. 10). Results of our analyses revealed a strong decline in cephalopod species with large embryonic shells and in cephalopods with demersal juvenile or adult stages. By contrast, cephalopod species with a planktotrophic juvenile strategy and pelagic mode of life were not affected during this crisis in total cephalopod diversity (Time slice F, Figs 6, 7). The latter life strategies also dominated in the Lochkovian cephalopod faunas.

The above mentioned facts clearly show that the tremendous global decrease in cephalopod species diversity in the latest Silurian was caused by processes affecting cephalopod taxa having a long incubation period and living during later ontogeny close to the bottom. This phenomenon can be interpreted as precursor of intense radiation of cephalopods in the Emsian (Klug et al. 2010), especially of the Bactritoidea and Ammonoidea. Speculatively, the orthoceratid ancestors of these two groups might shared a trait with these two more derived taxa, which guaranteed the evolutionary and ecological success of all three. Perhaps, it was the reproductive rates, as reflected in small embryonic shells of these three groups.

\section{Relationship between biodiversity changes and the transgressive/regressive curve}

Analysis of the relationship between cephalopod biodiversity changes and the transgressive/regressive curve is not trivial because a global transgressive/regressive curve with high stratigraphic resolution has never been published for the time frame under consideration. There is a general consensus on the mid-Př́idolí high stand and the general regressive conditions, which continued until the earliest Devonian (Johnson et al. 1998). A sea-level curve based on the interpretation of sedimentological data from the Prague Basin may be affected by local tectonics, as has been documented by Kř́ž (1998a) for Silurian rocks. The most recent synthesis of Palaeozoic sea-level changes (Haq \& Schutter 2008) indicates two high-stands during the Přídolí in the Prague Basin curve (also documented in the Appalachian Basin and in Novaya Zemla, see Bell \& Smosna 1998). If the curve correctly reflects global sea-level changes during the Přídolí, the results of our preliminary analysis of the relationship between cephalopod biodiversity changes and the transgressive-regressive

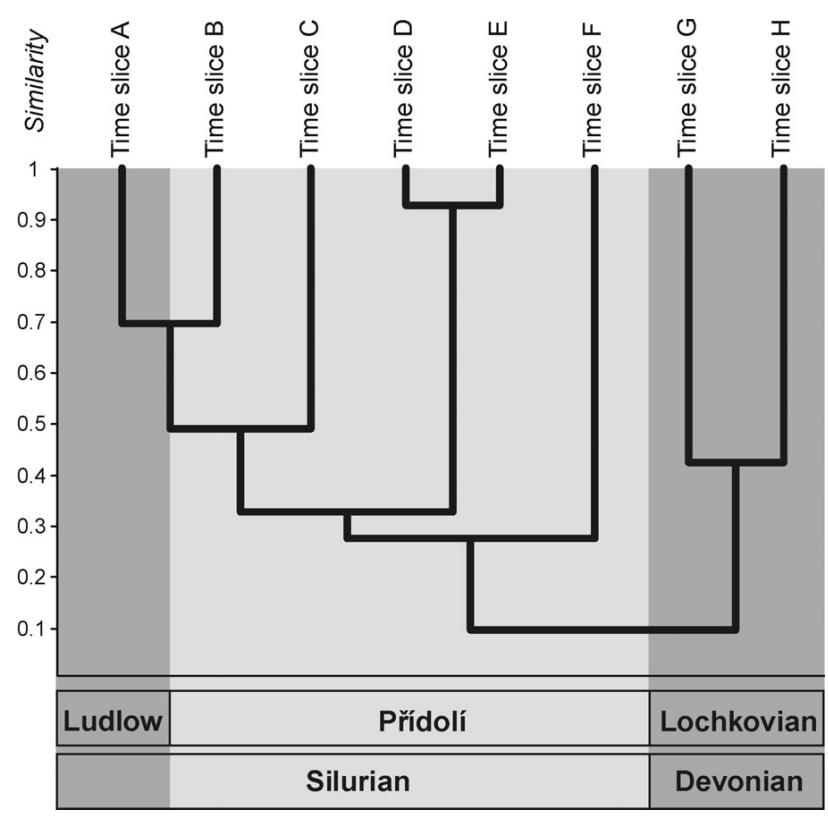

Figure 9. Dendrogram based on clustering of DICE similarities using unweighed pair-group average algorithm.

curve can be considered as being global. Present data suggests that there is no strong link between sea-level changes and cephalopod biodiversity. Nevertheless, our Time slices do not exactly correlate with the transgressive/regressive curve. By contrast, the change in diversity (and composition of the assemblages) between Time slices B and D corresponds well with the Přídolí high-stand (Johnson et al. 1998).

\section{Relationship between cephalopod biodiversity changes and global carbon cycle}

Analysis of $\delta^{13} \mathrm{C}$ evolution in the global marine reservoir, based on samples from the Prague Basin, clearly revealed a distinct and statistically significant increase in $\delta^{13} \mathrm{C}$ values during the Přídolí from Time slices $\mathrm{C}$ to $\mathrm{F}$. The earliest Lochkovian is characterized by the same $\delta^{13} \mathrm{C}$ values with a decreasing trend in the younger Lochkovian. Therefore, the latest Silurian (Time slice F - LAD of Monograptus transgrediens to FAD of Monograptus uniformis) was a time of change in dynamics of the global carbon cycle in the marine ecosystem and the early Lochkovian is characterised by steady conditions following this change. Our data agree well with results of earlier publications (Andrew et al. 1994, Hladíková et al. 1997, Porebska \& Sawlowicz 1997, Saltzman 2002, Buggish \& Mann 2004, Malkowski et al. 2009). However, in some cases, a detailed comparison of the $\delta^{13} \mathrm{C}$ curve with data from the Prague Basin (GSSP area) is difficult because of the lack of highresolution biostratigraphic data. 
EARLY STAGES

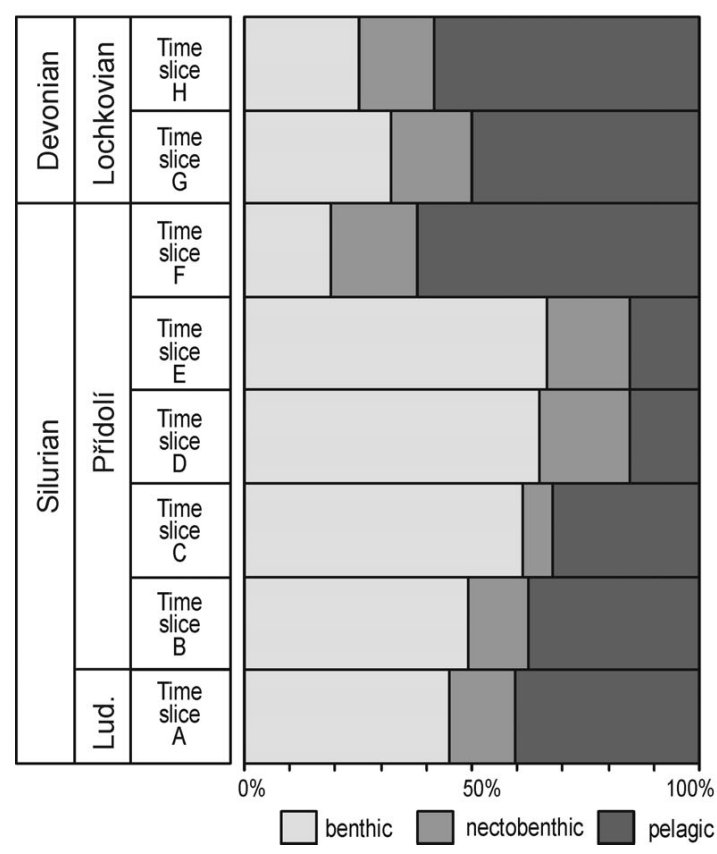

ADULTS

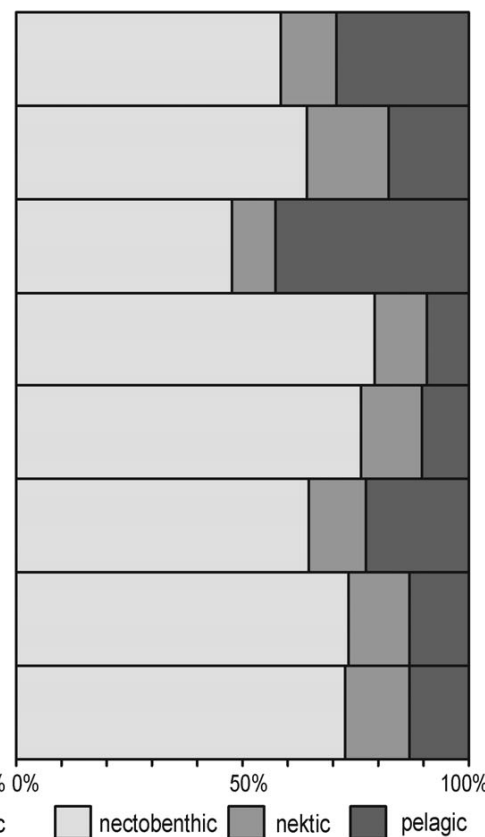

Figure 10. Relative diversity of cephalopods with different embryonic and adult strategies.
Our results show, in contrast to sea-level changes, a distinct relationship between cephalopod biodiversity changes and the global carbon cycle. Time slice F (latest Silurian) was not only a time of change in dynamics in the global carbon cycle, but also a time of tremendous decrease in the global diversity of cephalopod species, mainly affecting cephalopod taxa having a long incubation period and living close to the bottom during later ontogeny.

\section{Relationship between cephalopod biodiversity changes and the Silurian-Devonian boundary crises}

Three differrent bioevents - the Silurian-Devonian boundary Event (Walliser 1985), Transgrediens Event (Urbanek 1995), and Klonk Event (Jeppsson 1998) - were defined within the Silurian-Devonian boundary interval. These terms are unfortunately used differently in recent publications. The Silurian-Devonian boundary Event was proposed by Walliser (1985) who defined it by the first occurrence of Monograptus uniformis. This bioevent is thus identical with the Silurian-Devonian boundary (e.g., Chlupáč et al. 1972). Schönlaub (1986) characterized this bioevent as the period "...when new environments were established". Later, Walliser (1996) reviewed the available data and described also this stratigraphic level as a time of distinct environmental changes. Boucot (1990) did not consider this event as an extinction event. Similarly, Talent et al. (1993) did not find any significant change in generic diversity of brachiopods across the Silurian-Devonian boundary. House (2002) confused the Silurian-Devonian boundary
Event with the Klonk Event. According to the published data, the Silurian-Devonian boundary is thus not connected with distinct extinction events.

In contrast to the Silurian-Devonian boundary Event, the Transgrediens Event was introduced as an extinction event. Urbanek (1995) defined it as a graptolite extinction event close to the LAD of $M$. transgrediens. Similarly, Jeppsson (1998) introduced the name "Klonk SecundoUnnamed Event" as a conodont extinction event, which is probably identical with the Transgrediens Event and which "started at or possibly before the extinction of ' $P$.' transgrediens, at or near the replacement of Oulodus elegans elegans by O. elegans detorta". Jeppsson thus only established a new name for the same crisis and therefore, we give the priority to the older name Transgrediens Event.

All bioevents mentioned above were based on the evaluation of diversity dynamics of a few graptolite or conodont species. It is thus questionable if these graptolite or conodont crises really represent crises in the global marine ecosystem.

Our analysis of the large cephalopod species dataset revealed the highest relative extinction rate in Time slice E, which also has the highest cephalopod species diversity at 110 species. Before the end of Time slice E, i.e., before the LAD of $M$. transgrediens, more than $80 \%$ of all cephalopod species became extinct. However, high extinction rates also characterise the latest Silurian and early Lochkovian (Time slices F and G, see Figs 6, 7). The beginning of the Lochkovian is a time of high origination rate. Cephalopod diversity data show that the crisis happened during time slices E and F (end of Silurian), when the number of extinct cephalopod species was about six to 
seven times higher than the number of originating cephalopod species. Contrariwise, the earliest Devonian (early Lochkovian) was a time of recovery after the end-Silurian crises (Figs 6, 7), when one order (Ascocerida), one suborder (Tarphycerina), nine families (e.g. Hemiphragmoceratidae and Mandaloceratidae), and several genera became extinct.

\section{Interpretation and conclusions}

Our results revealed a correlation between cephalopod biodiversity and the global carbon cycle. The latest Silurian (Time slice F) was not only a time of change in dynamics of the global carbon cycle, but also a time of tremendous decrease in the global diversity of cephalopod species. This decline affected mainly cephalopod taxa having a long incubation period and living close to the bottom during their later ontogeny, reflecting possibly a selection for a certain habitat. Selective extinction of these species may be a key to understanding the causes of this crisis.

Based on their analyses of rock geochemistry and graptolite distribution from pelagic sequences in the Polish Bardzkie Mountains, Porebska \& Sawlowicz (1997) noted that the latest Silurian M. transgrediens Zone and the earliest Devonian M. uniformis Zone were separated by a thin interval termed a linograptid "interregnum". They interpreted a distinct change in geochemical composition of the sediments of the linograptid "interregnum" as evidence for a short-term shallowing of the upwelling system, which brought nutrient-rich water. This change in graptolite fauna above the LAD of Monograptus transgradiens was, according to Porebska \& Sawlowicz (1997), caused by a high productivity of cyanobacteria, which consequently increased the level of the anoxic layer. An upwelling of anoxic water was fatal for uniserial, straight monograptid colonies living deeper (close to the base of the mixed layer or near the top of the denitrification zone) than Linograptus populations. A high content of rhenium in sediments of the linograptid "interregnum" is also supporting a decrease in oxygen content of seawater. Porebska \& Sawlowicz's model (1997) also explains the demersal cephalopod species diversity decline as well as its low impact on the diversity of pelagic cephalopods.

Recent data on global seawater temperature (Joachimski et al. 2009) indicates a progressive cooling during the Přídolí, reaching a minimum global ocean temperature in the earliest Lochkovian. This cooling corresponds well with the regressive trend and the higher erosion rate causing an increase in ${ }^{87} \mathrm{Sr} /{ }^{86} \mathrm{Sr}$ isotope values for marine carbonates (Veizer et al. 1999, Frýda et al. 2002). The relationship between seawater temperature and global oceanic circulation was discussed in detail by several authors (e.g., Wilde \& Berry 1984, 1986; Schopf 1980;
Bralower \& Thierstein 1980; Jeppsson 1990 etc.). These studies clearly showed that progressive cooling could trigger a deepening of cooler and denser seawater (at a temperature of about $5^{\circ} \mathrm{C}$ ) at high latitudes and thus change global oceanic circulation. The subsequent upwelling of nutrient-rich water could have represented a new food supply for marine animals. The observed progressive increase in TOC and $\delta^{13} \mathrm{C}$ values during the Přídolí could well reflect an increase in bioproductivity. New food sources may also explain the observed increase in cephalopod diversity. An anoxic or disoxic event in the period between LAD $M$. transgrediens and the first Devonian M. uniformis Zone (Porebska \& Sawlowicz 1997) probably selectively affected benthic communities (thus also demersal cephalopods). This process was perhaps responsible for the strong decrease in total biodiversity and subsequently caused a lowering of bioproductivity and thus the steady conditions in $\delta^{13} \mathrm{C}$ composition of seawater during the early Lochkovian. Such a destruction of faunal communities could have altered the global carbon cycle of the marine ecosystem in the highest Silurian. Regardless of the end-Silurian crises in benthic communities, the early Lochkovian seawater was still nutrient-rich, which could explain the fast recovery rate of the marine ecosystem (Fig. 6) and subsequent Palaeozoic Plankton (Nützel \& Frýda 2003) and Nekton Revolutions (Klug et al. 2010). Our data also show that the extinction interval was much longer (from the end of Time slice $E$ to the beginning of the Lochkovian) than had been suggested by graptolite and conodont biodiversity studies. Usage of terms such as the Silurian-Devonian boundary Event (Walliser 1985), Transgrediens Event (Urbanek 1995), and Klonk Event (Jeppsson 1998) thus requires a detailed revision.

\section{Acknowledgements}

This work was supported by grants from the Czech-American Cooperation Programme (Kontakt ME08011) and the Grant Agency of the Czech Republic (205/08/0062 and 205/09/0703). The authors thank Christian Klug (Zürich) and Michal Mergl (Plzeň) for their helpful reviews.

\section{References}

AndRew, A.S., HAMilton, P.J., MAWson, R., TAlent, J.A. \& WHITFORD, D.J. 1994. Isotopic correlation tools in the midPaleozoic and their relation to extinction events. Austalien Petroleum Exploration Association Journal 34, 268-277.

AZMY, K., VEIZER, J., WENZEL, B., BASSETT, M.G. \& COPPER, P. 1999. Silurian strontium isotope stratigraphy. Geological Society of America Bulletin 111, 475-483.

DOI 10.1130/0016-7606(1999) $111<0475$ :SSIS > 2.3.CO;2

BABIN, C. 1966. Mollusques bivalves et céphalopodes du 
Paléozö̈que armoricain. Étude systèmatique. Essai sur la phylogénie des Bivalves. Esquisse paléoécologique. 438 pp. Imprimérie commerciale et administrative, Brest.

Babin, C., Deunff, J., Mélou, M., Paris, F., Pelhate, A., PlusquelleC, Y. \& RACheboeUf, P.R. 1979. La coupe de Porzar Vouden (Pridoli de la presqu'ile de Crozon) Massif Armoricain. Palaeontographica, Abteilung A 164, 52-84.

BARRANDE, J. 1846. Notice préliminaire sur le Systême silurien et les Trilobites de Bohême. 97 pp. Published privately, Leipzig.

BARRANDE, J. 1865-1877. Systęme silurien du Centre de la Bohême, Ire partie: Recherches Paléontologiques, vol. II, Classe de Mollusques, Ordre des Céphalopodes. 1865: Série 1, planches 1-107; 1866: Série 2, planches 108-244; 1867: Série 3, 712 pp.; 1868: Série 4, planches 245-350; 1870: Série 5, 266 pp., Série 6, planches 351-460; 1874: Série 7, 804 pp.; 1877: Série 8, 742 pp., Série 9, 743 pp., Supplement 1, 297 pp., supplement 2 , planches 461-544. Privately published, Prague \& Paris.

BARrois, M.C., Pruvost, P. \& Dubois, G. 1912. Faune SiluroDévonienne du L'Escarpelle. Mémoires de la Société géologique du Nord 6, 128-150.

BARSKOV, I.S. 1963. System and phylogeny of the Pseudorthoceratidae. Biulleten moskovskogo obshchestva ispytatelei prirody, Otdel geologitcheskii 38, 149-150.

Bell, S.C. \& SMOSNA, R. 1998. Pridoli sea-level fluctuations and sequence stratigraphy in the Appalachian basin, USA. Temas Geológico 23, 51-53.

BERDAN, J.M. 1969. Siluro-Devonian boundary in North America. Geological Society of America Bulletin 80, 2165-2174. DO1 10.1130/0016-7606(1969)80[2165:SBINA]2.0.CO;2

BoGOLEPOVA, O.K. 1998. Silurian cephalopods: New data from the Carnic Alps of Austria. Temas Geológico 23, 60-62.

Bogolepova, O.K., GutiéRREZ, J.C. \& RobARdET, M. 1998. A brief account on the Upper Silurian cephalopods from the Valle syncline, province of Seville (Ossa Morena Zone, southern Spain). Temas Geológico 23, 63-66.

BOUČEK, B. 1966. Eine neue und bisher jüngste Graptolithenfauna aus dem böhmischen Devon. Neue Jahrbuch für Geologie und Paläeontologie, Monatshefte 3, 161-168.

BOUČEK, B., HORNÝ, R. \& CHLUPÁČ, I. 1966. Silurian versus Devonian. Sborník Národního muzea, Řada B 22, 49-65.

BouCOT, A. 1990. Phanerozoic extinctions: how similar are they to each other. Lecture Notes Earth History 30, 5-20. DOI $10.1007 / \mathrm{BFb} 0011131$

BUGGISCH, W. \& MANN, U. 2004. Carbon isotope stratigraphy of Lochkovian to Eifelian limestones from the Devbonian of central and southern Europe. International Journal of Earth Sciences 93, 521-541.

CALNER, M. 2008. Silurian global events - at the tipping point of climate change, 21-58. In ASHRAF, M.T. (ed.) Mass extinctions. Springer-Verlag, Berlin \& Heidelberg

CARls, P., SlavíK, L. \& VAlENZuela-Ríos, J.I. 2007. Revisions of conodont biostratigraphy across the Silurian-Devonian boundary. Bulletin of Geosciences 82(2), 145-164. DOI 10.3140/bull.geosci.2007.02.145

CHEN, J., LIU, G. \& CHEN, T. 1981. Silurian nautiloid faunas of Central and Southwestern China. Memoires of Nanjing Institut of Geology and Palaeontology 13, 1-104.

CHLUPÁČ, I. 1953. Stratigrafická studie o hraničních vrstvách mezi silurem a devonem ve středních Čechách (Stratigraphical investigation of the border strata of the Silurian and the Devonian in the Central Bohemia). Sborník Ústředního ústavu geologického, Oddíl geologický 20,277-347.

CHLUPÁČ, I. 1971. Some trilobites from the Silurian/Devonian boundary beds of Czechoslovakia. Palaeontology 14, 159-177.

CHLUPÁČ, I. 1977. Barrandian. The Silurian-Devonian Boundary. IUGS Serie A 5, 84-95.

CHLUPÁČ, I. 1983. Trilobite assemblages in the Devonian of the Barrandian area and their relations to palaeoenvironments. Geologica et Palaeontologica 17, 45-73.

CHLuPÁČ, I. 1998. DEVONIAN, 101-133. In HAVLíčEK, V., KŘíž, J., KuKal, Z. \& ŠTORCH, P. Palaeozoic of the Barrandian (Cambrian to Devonian). Český geologický ústav, Praha.

ChlupÁČ, I., JAEger, H. \& ZIKMundovÁ, J. 1972. The Silurian-Devonian boundary in the Barrandian. Bulletin of Canadian Petroleum Geology 20, 104-174.

CRICK, R.E., EllwoOd, B.B., Hladil, J., Hassani, A.El., HROUdA, F. \& CHLUPÁČ, I. 2001. Magnetostratigraphy susceptibility of the Pridolian-Lochkovian (Silurian-Devonian) GSSP (Klonk, Czech Republic) and a coeval sequence in Anti-Atlas Morocco. Palaeogeography, Palaeoclimatology, Palaeoecology 167, 73-100. DOI 10.1016/S0031-0182(00)00233-9

DAHMER, G. 1951. Die Fauna der nach-ordovizischen VerseSchichten. Mit Ausschluss der Trilobiten, Crinoiden und Anthozoen. Palaeontographica, Abteilung A 101, 1-152.

DZIK, J. 1982. Origin of the Cephalopoda. Acta Palaeontologica Polonica 26, 161-191.

DZIK, J. 1984. Phylogeny of the Nautiloidea. Palaeontologia Polonica 45, 1-255.

DZIK, J. \& KISELEV, G. 1995. The baltic nautiloids Cyrtoceras ellipticum Lossem, 1860, Cyrtoceras priscum Eichwald, 1861 and Orthoceras damesi Krause, 1877. Paläontologische Zeitschrift 69, 61-71.

ENGESER, T. 1996. The position of the Ammonoidea within the Cephalopoda, 3-23. In LANDMAN, N.H., TANABE, K. \& DAVIS, R.A. (eds) Ammonoid Paleobiology. Plenum Press, New York.

ERIKSSON, M.J. \& CALNER, M. 2008. A sequence stratigraphical model for the late Ludfordian (Silurian) of Gotland, Sweden implications for timing between changes in sea-level, palaeoecology, and the global carbon cycle. Facies 54, 253-276. DOI 10.1007/s10347-007-0128-y

FERRETTI, A. \& KŘíž, J. 1995. Cephalopod limestone biofacies in the Silurian of the Prague Basin, Bohemia. Palaios 10, 240-253. DOI $10.2307 / 3515255$

FLOWER, R.H. 1957. Nautiloids of the Paleozoic. Memoirs of the Geological Society of America 67, 829-852.

Flower, R.H. \& TEICHERT, C. 1957. The cephalopod order Discosorida. University of Kansas Paleontological Contributions, Mollusca 6, 1-144.

FoERSTE, A.F. 1926. Actinosiphonate, Trochoceroid and Other Cephalopods. Bulletin Denision University, Journal of the Scientific Laboratories 21, 285-384.

FRÝDA, J., HLADIL, J. \& VOKURKA, K. 2002. Seawater strontium isotope curve at the Silurian/ Devonian boundary: a study of the global Silurian/Devonian stratotype. Geobios 35, 21-28.

FRÝDA, J. \& MANDA, Š. 1997. A gastropod faunule from the Monograptus uniformis Biozone (Early Lochkovian, Early 
Devonian) in Bohemia. Mittelungen Geologische-Paläeontologische Institut Universität Hamburg 80, 59-122.

GNOLI, M. 1982. Lower Devonian orthocone cephalopods from Iglesiente and Sulcis regions (southwestern Sardinia). Bollettino della Società Paleontologica Italiana 21, 73-98.

GNOLI, M. 1987. Revision and autecological remarks of the species Columenoceras grande (Meneghini, 1857) (Nautiloidea, Orthocerida). Bollettino della Società Paleontologica Italiana 26, 245-249.

GNOLI, M. 1997. A further contribution towards the taxonomic revision of Silurian nautiloid cephalopods erected and/or reported by J. Barrande in the last century in the Barrandian (Central Bohemia). Acta Universitatis Carolinae, Geologica $24,15-45$.

GNOLI, M. 2003. Northern Gondwanan Siluro-Devonian palaeogeography assessed by cephalopods. Palaeontologia Electronica $5,1-19$.

GNOLI, M. \& SeRPAGLI, E. 1991. Nautiloid assemblages from middle-late Silurian of Southwestern Sardinia: a proposal. Bollettino della Società Paleontologica Italiana 30, 187-195.

Gosselet, J., BArrois, C., Leriche, M. \& CREPIN, A. 1912. Description de la faune siluro-dévonienne de Liévin. Mémoires de la Societé géologique du Nord 6, 1-225.

Gradstein, F.M., OGG, J.G. \& SMITH, A.G. 2004. A Geologic Time Scale 2004. 589 pp. Cambridge University Press, Cambridge.

HAQ, B.U. \& SCHUTTER, S.R. 2008. A chronology of Paleozoic sea-level changes. Science 322, 64-68.

HAVLÍČEK, V. 1999. Lochkovian brachiopods of the Prague Basin. Věstník Českého geologického ústavu 74, 299-322.

HAVLÍČEK, V. \& ŠTORCH, P. 1999. Silurian and Lochkovian Communities of the Prague Basin (Barrandian area, Czechoslovakia), 200-228. In BOUCOT, A.J. \& LAwSON, J.D. (eds) Final report, project Ecostratigraphy. Paleocommunities: A case study from the Silurian and Lower Devonian. Cambridge University Press, Cambridge.

HERITSCH, F. 1930. Die obersilurische Fauna des Wiedatales im Harz. Jahrbuch der Preussischen Geologischen Landesanstalt zu Berlin für das Jahr 1929, Teil 2, 514-580.

Histon, K. 2002. A nautiloid assemblage from the Upper Silurian (Pridoli) of the Carnic Alps, Austria. Special Papers in Palaeontology 67, 115-134.

Histon, K., Hubmann, B. \& Messner, F. 2010. A preliminary study of the upper Silurian nautiloid cephalopods from the Eggenfeld section (Graz Paleozoic, Austria). Bollettino della Società Paleontologica Italiana 49(1), 65-74.

HLADíkOVÁ, J., HLADIL, J. \& KŘíBEK, B. 1997. Carbon and oxygen isotope record across Pridoli to Givetian stage boundaries in the Barrandian basin (Czech Republic). Palaeogeography, Palaeoclimatology, Palaeoecology 132, 225-241.

HLADIL, J. 1992. Are there turbidites in the Silurian/Devonian boundary stratotype? (Klonk near Suchomasty, Barrandian, Czechoslovakia). Facies 26, 35-54.

HollAND, C.H. 1984. Form and function in Silurian cephalopoda. Special Papers in Palaeontology 32, 151-164.

HoLLAND, C.H. 1991. What is so very special about the Silurian? Special Papers in Palaeontology 44, 391-397.

HoLLAND, C.H. 2000. Rare cephalopods from the Prrídolí of England and Wales. Geological Journal 35, 25-31.

HORNÝ, R. 1961. Hraniční fauna vrstev přídolských a lochkov- ských v Barrandienu. Věstník Ústředního ústavu geologického $36,381-384$.

HORNÝ, R. 1962. Das mittelböhmische Silur. Geologie 11, 873-916.

HORNÝ, R. 1955. Studie o vrstvách budňanských v západní části Barrandienu. Sborník Ústředního ústavu geologického, Oddíl geologický 21, 315-447.

HORNÝ, R. 1956. O rodu Dawsonoceras Hyatt, 1884 (Nautiloidea) ze středočeského siluru. Sborník Ústředního ústavu geologického, Oddíl paleontologický 22, 425-452.

HORNÝ, R. 1965. Corbuloceras gen. n., nový onkoceridní hlavonožec (Cephalopoda, Oncocerida) z českého siluru. Časopis Národního muzea, Oddíl př́rodovědný 134, 132-137.

House, M. 2002. Strength, timing, setting and cause of midPalaeozoic extinctions. Palaeogeography, Palaeoclimatology, Palaeoecology 181, 5-25.

DOI $10.1016 / \mathrm{S} 0031-0182(01) 00471-0$

HyATT, A. 1883-1884. Genera of fossil cephalopods. Proceedings of the Boston Society of Natural History 22, 273-338.

HyATT, A. 1894. Phylogeny of an Acquired characteristic. Proceedings American Philosophical Society 32, 349-647.

HyATT, A. 1900. Cephalopoda, 502-592. In ZiTTEL, K.A. \& EASTMAnN, C.R. (eds) Textbook of Palaeontology, volume 1. Boston.

JAEGER, H. 1960. Das höhere Silur in Thüringen, 290-342. In SvobodA, J. (ed.) Prager Arbeitstagung uber die Stratigraphie des Silurs und des Devons 1958. Ústřední ústav geologický, Praha.

JAEGER, H. 1991. Neue standard graptolithen zonenflogen nach der Grosen krise an der Wenlock/Ludlow grenze (Silur). Neue Jahrbuch für Geologie und Paläontologie, Abhandlungen 182, 303-354.

JANISECHEVSKIJ, M. 1917. On some representatives of the upper Silurian Fauna of the Caucasus. Annuaire de la Societé Paleontologique de Russie 2, 47-64.

JEPPSSON, L. 1990. An oceanic model for lithological and faunal changes tested on the Silurian record. Journal of the Geological Society 147, 663-674. DO] 10.1144/gsjgs.147.4.0663

JEPPSSON, L. 1998. Silurian Oceanic Events: Summary of General Characteristic. New York State Museum Bulletin 491, 239-257.

JEPPSSON, L. \& ALDRIDGE, R.J. 2000. Ludlow (late Silurian) oceanic episodes and events. Journal of the Geological Society 157, 1137-1148. DOI 10.1144/jgs.157.6.1137

JOACHIMSKI, M.M., BREISIG, S., BUGGISCH, W., TALENT, J.A., Mawson, R., Gereke, M., Morrow, J.R. DAY, J. \& WEDDIGE, K. 2009. Devonian climate and reef evolution: Insights from oxygen isotopes in apatite. Earth and Planetary Science Letters 284, 599-609. DOI 10.1016/j.eps1.2009.05.028

JOHNSON, M.E., RONG, J. \& KERSHAW, S. 1998. Calibrating Silurian eustasy against the erosion and burial of coastal paleotophography. New York State Museum Bulletin 491, 3-13.

KaufMann, B. 2006. Calibrating the Devonian time scale: A synthesis of U-Pb ID-TIMS ages and conodont stratigraphy. Earth Science Reviews 76, 175-190. DOI 10.1016/j.earscirev.2006.01.001

KISELEV, G.N. 1984. Golovonogiye mollyuski silura i nizhnego devona severa Urala. $143 \mathrm{pp}$. Izdatel'stvo Leningradskogo Universiteta, Leningrad.

KiseleV, G.N., MironOVA, M.G. \& SinitsinA, I.N. 1987. Atlas 
siluriiskikh mollyuskov Podolii. 180 pp. Izdatel'stvo Leningradskogo Universiteta, Leningrad.

KiseleV, G.N., SAVICKYJ, J.V., SinitsinA, I.N. \& MironOvA, M.G. 1993. Atlas mollyuskov i brachiopod silura i devona yuzhnogo Tyan-Shanya. 115 pp. Izdatel'stvo St. Peterburskogo Universiteta, St. Petersburg.

KiseleV, G.N., SinitsinA, I.N. \& MiRonovA, M.G. 1990. Atlas mollyuskov verchego ordovika i silura severozapada Vostochno-Evropeiskoi platformy. 77 pp. Izdatel'stvo St. Peterburskogo Universiteta, St. Petersburg.

Klug, C., KrÖger, B., Kiessling, W., Mullins, G.L., SERVAIS, T., FrÝDA, J., KORN, D., TURNER, S. \& MARX, K. 2009. The Devonian nekton revolution. Lethaia, published online, 13 pp. DOI 10.1111/j.1502-3931.2009.00206.x

KolebABA, I. 1973. Embryonální stádia hlavonožců ze svrchních poloh Liteňského souvrství (silur, spodní wenlock). Časopis Národního muzea, Oddíl prírodovědný 142, 28-40.

KolebABA, I. 1975. Caliceras n. gen. and ontogeny of C. capillosum (Barrande) (Nautiloidea, Michelinoceratida). Časopis pro mineralogii a geologii 20, 377-392.

KoleBABA, I. 1977. New information on longitudinally sculptured orthocerids. Časopis pro mineralogii a geologii 22, 125-138.

KoleBABA, I. 1999. Gradual opening of the siphonal tube in an orthoconic cephalopod from the Silurian of Central Bohemia (Czech Republic). Journal of the Czech Geological Society 44, 131-136.

KolebABA, I. 2002. A contribution to the theory of the cameral mantle in some Silurian Nautiloidea (Mollusca, Cephalopoda). Bulletin of the Czech Geological Survey 77, 183-186.

KoREN', T.N. 1993. Main event levels in the evolution of the Ludlow graptolites. Geological Correlation 1, 44-52.

KrausE, A. 1877. Die fauna der Beyrichien and Chonetenkalke des nordeutschen Diluviums. Zeitschrift der Deutsche Geologische Gesselschaft 29, 1-49.

KREJČÍ, J. 1877. Geologie čili nauka o vrstvách zemských se zvláštním ohledem na krajiny českoslovanské. 1035 pp. Řivnáč, Praha.

KŘİŽ, J. 1998a. Silurian, 79-101. In CHLUPÁČ, I., HAVLÍČEK, V., KŘíž, J., KuKal, Z. \& ŠTorCh, P. Paleozoic of the Barrandian (Cambrian to Devonian). Český geologický ústav, Praha.

Kříž, J. 1998b. Recurrent Silurian-Lowest Devonian Cephalopod Limestones of Gondwanan Europe and Perunica. New York State Museum Bulletin 491, 183-198.

KŘíž, J. 1999. Bivalvia dominated communities of Bohemian type from the Silurian and Lower Devonian carbonate facies, 225-248. In Boucot, A.J. \& LAwson, J.D. (eds) Final report, project Ecostratigraphy. Paleocommunities: A case study from the Silurian and Lower Devonian. Cambridge University Press, Cambridge.

KŘíž, J. 2008a. Algerina gen. nov. (Bivalvia, Nepiomorphia) from the Silurian of the North Gondwana margin (Algeria), peri-Gondwanan Europe (France, Italy), Perunica (Prague Basin) and the Siberian plate (Tajmyr Basin, Russia). Bulletin of Geosciences 83(1), 79-84.

DOI 10.3140/bull.geosci.2008.01.079

Ǩ̌́ľ̌, J. 2008b. A new bivalve community from lower Ludlow of the Prague Basin. Bulletin of Geosciences 83(3), 237-280. DOI 10.3140/bull.geosci.2008.03.237
KŘíž, J., JAEGER, H., PARIS, F. \& SCHÖNLAUB, H.P. 1983. The Př́dolí Series as the fourth series of the Silurian System. A supplementary submission to the Subcommisiion on Silurian Stratigraphy, I.U.G.S. 159 pp. Dublin.

KŘíž, J., JAEGER, H., PARIS, F. \& SCHÖNLAUB, H.P. 1986. Přídolí - the fourth subdivision of the Silurian. Jahrbuch der Geologischen Bundesanstalt 129, 291-360.

KŘíž, J. \& PARIS, F. 1982. Ludlovian, Přídolian and Lochkovian in la Meignanne (Massif Armoricain): Biostratigraphy and correlations based on Bivalvia and Chitinozoa. Geobios 15, 391-421. DO1 10.1016/S0016-6995(82)80085-5

KRÖGER, B. 2006. Early growth-stages and classification of orthoceridan Cephalopods of the Darriwillian (Middle Ordovician) of Baltoscandia. Lethaia 39, 129-139.

DOI $10.1080 / 00241160600623749$

KRÖGER, B. 2008. Nautiloids before and during the origin of ammonoids in a Siluro-Devonian section in the Tafilalt, AntiAtlas, Morocco. Special Papers in Paleontology 79, 1-112.

KRÖGER, B. \& ISAKAR, M. 2006. Revision of annulated orthoceridan cephalopods of the Baltoscandic Ordovician. Fossil Record - Mitteilungen aus dem Museum für Naturkunde in Berlin 9, 137-163.

LEHNERT, O., ERIKSSON, M.J., CALNER, M., JOACHIMSKI, M. \& BUGGISCH, W. 2007a. Concurrent sedimentary and isotopic indications for global climatic cooling in the Late Silurian. Acta Palaeontologica Sinica 46, 249-255.

Lehnert, O., FrÝdA, J., Buggisch, W., Munnecke, A., NÜTZEL, A., KŘIIŽ, J. \& MANDA, Š. 2007b. $\delta^{13}$ C record across the Ludlow Lau Event: new data from mid palaeo-latitudes of northern peri-Gondwana (Prague Basin, Czech Republic). Palaeogeography, Palaeoclimatology, Palaeoecology 245, 227-244. DOI 10.1016/j.palaeo.2006.02.022

MALKOWSKI, K. \& RACKI, G. 2009. A global biogeochemical perturbation across the Silurian-Devonian boundary: Oceancontinent-biosphere feedbacks. Palaeogeography, Palaeoclimatology, Palaeoecology 276, 244-254. DOI 10.1016/j.palaeo.2009.03.010

MALKOWSKI, K., RACKI, G., DRYGANT, D. \& SZANIAWSKI, T. 2009. Carbon isotope stratigraphy across the Silurian-Devonian transition in Podolia, Ukraine: evidence for a global biogeochemical perturbation. Geological Magazine 146, 674-689. DO1 10.1017/S0016756809006451

MANDA, S. 2001. Some new or little known cephalopods from the Lower Devonian Pragian carbonate shelf (Prague Basin, Bohemia) with remarks on Lochkovian and Pragian cephalopod evolution. Journal of the Czech Geological Society 46, 269-286.

MANDA, Š. 2008. Palaeoecology and palaeogeographic relations of the Silurian phragmoceratids (Nautiloidea, Cephalopoda) of the Prague Basin (Bohemia). Bulletin of Geosciences 83(1), 39-62. DOI 10.3140/bull.geosci.2008.01.039

MANDA, Š. \& KŘíž, J. 2006. Environmental and biotic changes of the subtropical isolated carbonate platforms during Kozlowskii and Lau events (Prague Basin, Silurian, Ludlow). GFF 128, 161-168.

MANDA, Š. \& TUREK, V. 2009a. Revision of Pragian Rutoceratoidea Hyatt, 1884 (Nautiloida, Oncocerida) from the Prague Basin. Bulletin of Geosciences 84(1), 127-148. DOI 10.3140/bull.geosci.1118

MANDA, Š. \& TUREK, V. 2009b. Minute Silurian oncocerid nautiloids with unusual colour patterns. Acta Palaeontologica Polonica 54, 503-512. DOI 10.4202/app.2008.0062 
MANDA, Š. \& TUREK, V. 2009c. A Silurian oncocerid with preserved colour pattern and muscle scars (Nautiloidea). Bulletin of Geosciences 84(4), 755-766.

DOI 10.3140/bull.geosci.1168

MAREK, J. 1971. The genus Cyrtocycloceras Foerste, 1936 (Nautiloidea) from the Silurian of central Bohemia. Sborník geologických věd, Paleontologie 14, 107-133.

MAREK, J. 1998. Pallioceratida ordo n. - a new order of the Palaeozoic cephalopods (Mollusca, Cephalopoda). Bulletin of the Czech Geological Survey 73, 181-182.

MELCHIN, J.M., KOREN', T.N. \& ŠTORCH, P. 1998. Global diversity and survivorship patterns of Silurian graptoloids. New York State Museum Bulletin 491, 165-181.

Munnecke, A., SAmptleben, C. \& Bickert, T. 2003. The Irviken Event in the lower Silurian of Gotland, Sweden - relation to similar Palaeozoic and Proterozoic events. Palaeogeography, Palaeoclimatology, Palaeoecology 195, 99-124. DOI 10.1016/S0031-0182(03)00304-3

MUTVEI, H. 1957. On the relations of the principal muscles to the shell in Nautilus and some fossil nautiloids. Arkiv for Mineralogi och Geologi 2, 219-254.

MUTVEI, H. 2002. Nautiloid systematics based on siphuncular structure and position of muscle scars. Abhandlungen der Geologischen Bundesanstalt 57, 379-392.

NIKO, S. 1996. Pseudorthoceratid cephalopods from the Early Devonian Fukuji Formation of Gifu Prefecture, Central Japan. Transactions Proceedings Palaeontological Society Japan 181, 347-360.

NIKO, S. 1998. Kobayashiceras gifuense, a new actinocerid cephalopod from the lower Devonian of Japan. Journal of Paleontology 72, 36-38.

NIKO, S. 2003. First oncocerid cephalopod from Japan. Proceedings of the Japan Academy, Series B 79(4), 105-107. DOI 10.2183/pjab.79B.105

NoVÁK, O. 1886. Zur Kenntnis der Fauna der Etage F-f1 in der Palaeozoischen Schichtengroupe Böhmens. Sitzungsberichte der Königishe Böhmischen Gesellschaft der Wissenschaften, Jahrgang 1886, 1-23.

NUTZEL, A. \& FRÝDA, J. 2003. Paleozoic plankton revolution: evidence from early gastropod ontogeny. Geology 31, 829-831. DOI 10.1130/G19616.1

PoREBSKA, E. \& SAWlowiCZ, Z. 1997. Palaeoceanographic linkage of geochemical and graptolite events across the Silurian/Devonian boundary in Bardzkie Mountains (Southwest Poland). Palaeogeography, Palaeoclimatology, Palaeoecology 132, 343-354. DOI 10.1016/S0031-0182(97)00048-5

PRANTL, F. \& PřIBYL, A. 1948. Revision of the Bohemian Silurian Eurypterida. Rozpravy Státního geologického ústavu Československé republiky 10, 1-116.

PŘIBYL, A. 1940. Graptolitová fauna českého středního ludlow (Die Graptolithenfauna des mittleren Ludlows von Böhmen). Zprávy Geologického ústavu pro Čechy a Moravu 16, 63-73.

PŘIBYL, A. 1943. O stratigrafických poměrech siluru a devonu v podolské cementárně v Praze. Rozpravy České akademie věd a umění, Tř́da II 57, 1-20.

RisTEDT, H. 1968. Zur Revision der Orthoceratidae. Abhandlungen der mathematisch-naturwissenschaftlichen Klasse 4, $1-77$.

SALDZIUS, B.J. 1966. Fauna mollyuskov silurskikh otlozhenii yuzhnoy Pribaltiky. Paleontologiya $i$ stratigrafiya Pribaltiky $i$ Belorusii 1, 31-73.
SAlTZMAN, M.R. 2002. Carbon isotope $\left(\delta^{13} \mathrm{C}\right)$ stratigraphy across the Silurian-Devonian transition in North America: evidence for a perturbation of the global carbon cycle. Palaeogeography, Palaeoclimatology, Palaeoecology 187, 83-100. DOI 10.1016/S0031-0182(02)00510-2

SCHÖNLAUB, H.P. 1986. Significant geological events in the Paleozoic record of the Southern Alps (Austrian part), 163-167. In WALLISER, O.H. (ed.) Global Bio-events. Springer-Verlag, Berlin \& Heidelberg.

SCHOPF, T.J.M. 1980. Paleoceanography. 354 pp. Harvard University Press, Cambridge.

SERPAGLI, E. \& GNOLI, M. 1977. Upper Silurian cephalopods from Southwestern Sardinia. Bollettino della Società Paleontologica Italiana 16, 153-196.

ŠTORCH, P. 1995. Biotic crises and post-crisis recoveries recorded by graptolite faunas of the Barrandian area, Czech Republic. Geolines 3, 59-70.

STRIDSBERG, S. 1985. Silurian oncocerid cephalopods from Gotland. Fossils and Strata 18, 1-65.

StRIDSBERG, S. \& TUREK, V. 1997. A revision of the Silurian nautiloid genus Ophioceras Barrande. GFF 19, 21-36.

SvobodA, J. ed. 1960. Prager Arbeitstagung uber die Stratigraphie des Silurs und des Devons 1958. 518 pp. Ústřední ústav geologický, Praha.

SwEET, W. 1964. Nautiloidea-Orthocerida, 216-261. In MoORE, R.C. (ed.) Treatise on Invertebrate Paleontology, Part K, Mollusca. Geological Society of America, Lawrence.

TALENT, J.A., MAWSON, R., ANDREW, A.S., HAMILTON, P.J. \& WHITFORD, D.J. 1993. Middle Palaeozoic extinction events: Faunal and isotopic data. Palaeogeography, Palaeoclimatology, Palaeoecology 104, 139-152.

DOI 10.1016/0031-0182(93)90126-4

TEICHERT, C. 1933. Der Bau der actinoceroiden Cephalopoden. Palaeontographica, Abteilung A 78, 112-230.

TEICHERT, C. 1964. Actinoceratoidea, 190-216. In MoORE, R.C. (ed.) Treatise on Invertebrate Paleontology, Part K, Mollusca. Geological Society of America, Lawrence.

TUREK, V. 1975. Genus Kosovoceras gen. n. in the Silurian of Central Bohemia (Nautiloidea). Sborník geologických věd, Paleontologie 17, 7-39.

TUREK, V. 1976. Magdoceras gen. n. and Inclytoceras gen. n. from the Silurian of central Bohemia (Nautiloidea, Barrandeocerida). Časopis pro mineralogii a geologii 21, 137-145.

TUREK, V. 1983. Hydrodynamic conditions and the benthic community of upper Wenlockian calcareous shales in the western part of the Barrandian (Kosov Quarry). Časopis pro mineralogii a geologii 28, 246-260.

TUREK, V. 2008. Boionautilus gen. nov. from the Silurian of Europe and North Africa (Nautiloidea, Tarphycerida. Bulletin of Geosciences 83(2), 141-152.

DOI 10.3140/bull.geosci.2008.02.141

TUREK, V. 2010. Embryonic shells in some lechritrochoceratids (Nautiloidea, Barrandeocerida), 85-92. In TANABE, K. (ed.) Cephalopods. Present and past. Tokai University Press, Tokyo.

TUREK, V. \& MAREK, J. 1986. Notes on the phylogeny of the Nautiloidea. Paläontologische Zeitschrift 60, 245-253.

URBANEK, A. 1993. Biotic crises in the history of Upper Silurian graptoloids: A palaeobiological model. Historical Biology 7, 29-50. DOI 10.1080/10292389309380442

UrbaneK, A. 1995. Phyletic evolution in the latest Ludlow 
spinose monograptids. Acta Palaeontologica Polonica 40, $1-17$.

VANĚK, J. 1963. Zpráva o paleontologických výzkumech několika lokalit v siluru a devonu Barrandienu. Zprávy o geologických výzkumech $v$ roce 1962, 105-107.

Veizer, J., Ala, D., AZMY, K., Bruckschen, P., Buhl, D., Bruhn, F., CARden, G.A.F., Diener, A., EBNeth, S., Godderis, Y., Jasper, T., Korte, C., PAWEllek, F., PODLAHA, O.G. \& STRAUSS, H. 1999. ${ }^{87} \mathrm{Sr} /{ }^{86} \mathrm{Sr}, \delta^{13} \mathrm{C}$ and $\delta^{18} \mathrm{O}$ evolution of Phanerozoic seawater. Chemical Geology $161,59-88$. DOI $10.1016 / \mathrm{S} 0009-2541(99) 00081-9$

WALLISER, O.H. 1985. Natural boundaries and Commission boundaries in the Devonian. Courier Forschungsinstitut Senckenberg 75, 401-408.

WALliSER, O.H. 1996. Global events in the Devonian and Carboniferous, 225-250. In WALLISER, O.H. (ed.) Global Events and Event Stratigraphy in the Phanerozoic. Springer Verlag, Berlin.

WESTERMANN, G.E.G. 1998. Life Habits of Nautiloids,
263-298. In SAVAZZI, E. (ed.) Functional Morphology of the Invertebrate Skeleton. John Wiley, London.

WILDE, P. \& BERRY, W.B.N. 1984. Paleozoic (Cambrian through Devonian) anoxitropic biotopes. Palaeogeography, Palaeoclimatology, Palaeoecology 74, 3-13.

WILDE, P. \& BERRY, W.B.N. 1986. The role of oceanographic factors in the generation of global bio-events. Lecture Notes in Earth Sciences 8, 75-91. DO1 10.1007/BFb0010192

ZhURAVLEVA, F.A. 1972. Devonskie nautiloidei, Otryad Discosorida. Trudy Paleontologitscheskogo Instituta Akademie Nauk SSSR 134, 1-320.

ZHURAVleVA, F.A. 1974. Devonskyje nautiloidei, Otryady Oncoceratida, Tarphyceratida, Nautilida. Trudy Paleontologitscheskogo Instituta Akademie Nauk SSSR 142, 5-142.

ZHURAVLEVA, F.A. 1978. Devonskie nautiloidei, Nadotryad Orthoceratoidea. Trudy Paleontologitscheskogo Instituta Akademie Nauk SSSR 178, 1-224.

Zhuravleva, F.A. \& DoguZhaeva, L.A. 2004. Astrovioidea: A New Superorder of Paleozoic Cephalopods. Paleontological Journal 38, 1-73. 